\title{
Adaptive Development of Soil Bacterial Communities to Ecological Processes Caused by Mining Activities in the Loess Plateau, China
}

\author{
Zhanbin Luo ${ }^{1,2,+} \mathbb{C}$, Jing Ma ${ }^{3,+}{ }^{\mathbb{C}}$, Fu Chen ${ }^{1,3, * \mathbb{C}}$, Xiaoxiao $\mathrm{Li}^{1}$, Qi Zhang ${ }^{1}$ and Yongjun Yang ${ }^{1}$ \\ 1 School of Environment Science and Spatial Informatics, China University of Mining and Technology, \\ Xuzhou 221008, China; lzbin1991@cumt.edu.cn (Z.L.); lixiaoxiao@cumt.edu.cn (X.L.); \\ zhangqi2019@cumt.edu.cn (Q.Z.); y.yang@cumt.edu.cn (Y.Y.) \\ 2 College of Resources and Environment, Northwest A\&F University, Yangling 712100, China \\ 3 Low Carbon Energy Institute, China University of Mining and Technology, Xuzhou 221008, China; \\ jingma2013@cumt.edu.cn \\ * Correspondence: chenfu@cumt.edu.cn; Tel.: +86-5168-388-3501 \\ + These authors contributed equally to this work.
}

Received: 10 March 2020; Accepted: 26 March 2020; Published: 27 March 2020

\begin{abstract}
Microorganisms are the driving force behind the circulation and transformation of the soil substance. The development of soil bacterial communities is critical for ecosystem restoration and evolution. In the Loess Plateau, coal mining activities have aggravated the deterioration of the fragile local ecological environment. The adaptive development of soil bacterial communities in response to different ecological processes caused by coal mining activities was explored through high-throughput sequencing technology and an ecological network analysis of the mining subsidence area of the Daliuta Coal Mine and vegetation rehabilitation area of the Heidaigou Coal Mine in the Loess Plateau. The results showed that while mining subsidence was inhibited, vegetation rehabilitation promoted the soil physicochemical properties. Soil organic matter, available phosphorus and available potassium in the subsidence area decreased significantly $(P<0.05)$, while soil organic matter, soil water, $\mathrm{pH}$ and EC in the vegetation rehabilitation area increased significantly $(P<0.05)$. The diversity index in the subsidence area decreased by about $20 \%$, while that in the vegetation rehabilitation area increased by $63 \%$. Mining subsidence and vegetation rehabilitation had a distinct influence on the molecular ecological networks of the soil bacteria, which tended to be more complex after the mining subsidence, and the number of connections in the network increased otherwise significantly enhanced interactive relationships. After the vegetation rehabilitation, the number of modules in the ecological network increased, but the contents of modules tended to be simpler. Soil bacterial communities adapted to the changes by changing the relationships between bacteria in response to different ecological processes. This study provides new insights into the monitoring and abatement of the damaged ecological environment in mines.
\end{abstract}

Keywords: soil bacteria; molecular ecological network; mining subsidence; vegetation rehabilitation; Loess Plateau

\section{Introduction}

Coal has been an important propellant for industrial development [1]. Currently, China is the highest producer and consumer of coal in the world [2,3]. The Loess Plateau is the most important coal production base, constituting half of the coal production capacity of China. However, the ecological environment in this region is fragile, with serious land degradation, and the urgent need for ecological restoration $[4,5]$. While coal mining promotes the local economy, it also seriously damages the local 
natural environment [6,7]. With the increasing intensity of conflict between mining and ecological protection, the sustainable development of local society and the economy is hindered. This conflict has attracted widespread attention [8-10].

Coal mining interferes with ecosystems in several ways [8]. From 1987 to 2014, 1.3651 million hectares of land in China was damaged due to coal mining, with an average annual loss of 48,800 hectares [11]. The local ecological process changed due to surface excavation, crack, collapse, deep plowing, and waste stacking, resulting in various changes in soil physicochemical properties, seed banks and the microbial population [4,7,8,12-14]. Mining subsidence is an important phenomenon associated with underground mining, which causes the stretching, squeezing and fracture of soil, resulting in the greater change of soil moisture [15,16], decrease of soil bulk density $[17,18]$, a decrease of total soil porosity [19], and enhanced soil desertification [20]. Moreover, mining subsidence also changes the distribution and transport of soil nutrients, resulting in the decrease of $\mathrm{pH}$ [21], loss of organic matter [22], and the decrease of nitrogen, phosphorus and potassium contents [23]. Vegetation rehabilitation is an important remediation project for the ecological restoration of damaged mines, which can effectively improve the soil quality [24,25], improve the efficiency of soil water uptake [26], accelerate the accumulation of soil organic carbon [22,27], and protect biodiversity [28]. However, the influence of mining activities in different areas is usually complex, and normal principles do not quite apply. Therefore, the influence of coal mining activities on ecosystems should be discussed based on practical scenarios.

Microorganisms are the most active components in the soil environment and play key roles in organic matter decomposition and the cycling of nutrients [29-32]. Soil microorganisms are also very sensitive to external changes, so that they can serve as the indices to land degradation and ecological restoration $[33,34]$. With the development of sequencing technology, revealing the relationships between bacterial community structures and functions has become a highlight in ecological research $[35,36]$. Over recent years, soil bacterial communities in coal mining areas have drawn attention. Mining subsidence changes the support of the soil environment, and thereby negatively affecting the adaptability of soil bacteria and a decline in the number and activity of bacteria [37,38]. Even after 20 years of land reclamation in the coal mining area, the number of soil bacteria was still lower than that in an undisturbed area, but shrub coverage played a key role in ecological restoration [39]. Furthermore, vegetation rehabilitation could not only improve the richness of soil bacteria, but also promote the bacterial metabolism in original soil [29], which was found to be much higher than that in uncultivated soil [40,41]. After 5-14 years of vegetation rehabilitation, significant interactions were observed between plants and bacteria [42]. Some scholars suggest that the structure of soil bacteria after vegetation rehabilitation was dependent on $\mathrm{pH}$ and other abiotic characteristics [30]. Soil bacteria could serve as sensitive indicators of land degradation and ecological restoration $[43,44]$. However, previous studies on the impact of mining subsidence and vegetation rehabilitation on soil bacteria focused mainly on the changes in soil bacterial community structures, and not on the internal interactive relationships between bacterial communities. The development of bacterial communities and crucial bacterial microbes are still unclear.

Molecular ecological network analysis, as a recently developed method, can visually describe the complex potential structures and interactions among bacterial communities. This method is innovative in revealing the stability and complexity of ecological processes and functions [45-49]. Zhou et al. [50] and Lu et al. [51] studied the relationships and differences of soil bacterial communities in network structures, interactions and crucial species, under the conditions of high $\mathrm{CO}_{2}$ levels and continuous cropping of potato. Another study reported that increased precipitation enhanced the connections between the molecular ecological networks of soil bacteria [52]. As an intense surface disturbance, coal mining impacts the soil bacterial community [53]. Recently, we also observed that cracks reinforced the interactions among soil bacterial communities in the coal mining area of Loess Plateau [14]. However, due to technical limitations, the influence of mining subsidence and vegetation rehabilitation on the interactions between soil bacterial species has not been extensively evaluated. 
Therefore, here, the mining subsidence area of the Daliuta Coal Mine and the vegetation rehabilitation area of the Heidaigou Coal Mine in the Loess Plateau were studied to disclose: (1) the influence of mining subsidence and vegetation rehabilitation on the soil bacterial community structure; (2) the changes in the soil bacterial molecular ecological network after the mining subsidence and vegetation rehabilitation; (3) the interactions between soil bacterial communities and those between environmental factors caused by mining subsidence and vegetation rehabilitation. This study would also be theoretically beneficial for the ecological restoration of damaged mining areas in the Loess Plateau and shed light on the construction of green mines.

\section{Materials and Methods}

\subsection{Site Description}

The Loess Plateau is rich in coal resources, with a long history of coal mining, but the ecosystem has been greatly damaged (Figure 1a). In this study, the mining subsidence area of the Daliuta Mine in the northern part of the Loess Plateau and vegetation rehabilitation area of the Heidaigou Mine in Inner Mongolia Province were selected as the target regions. The locations of both regions are adjacent, and their climates, soil types, and soil textures are similar.
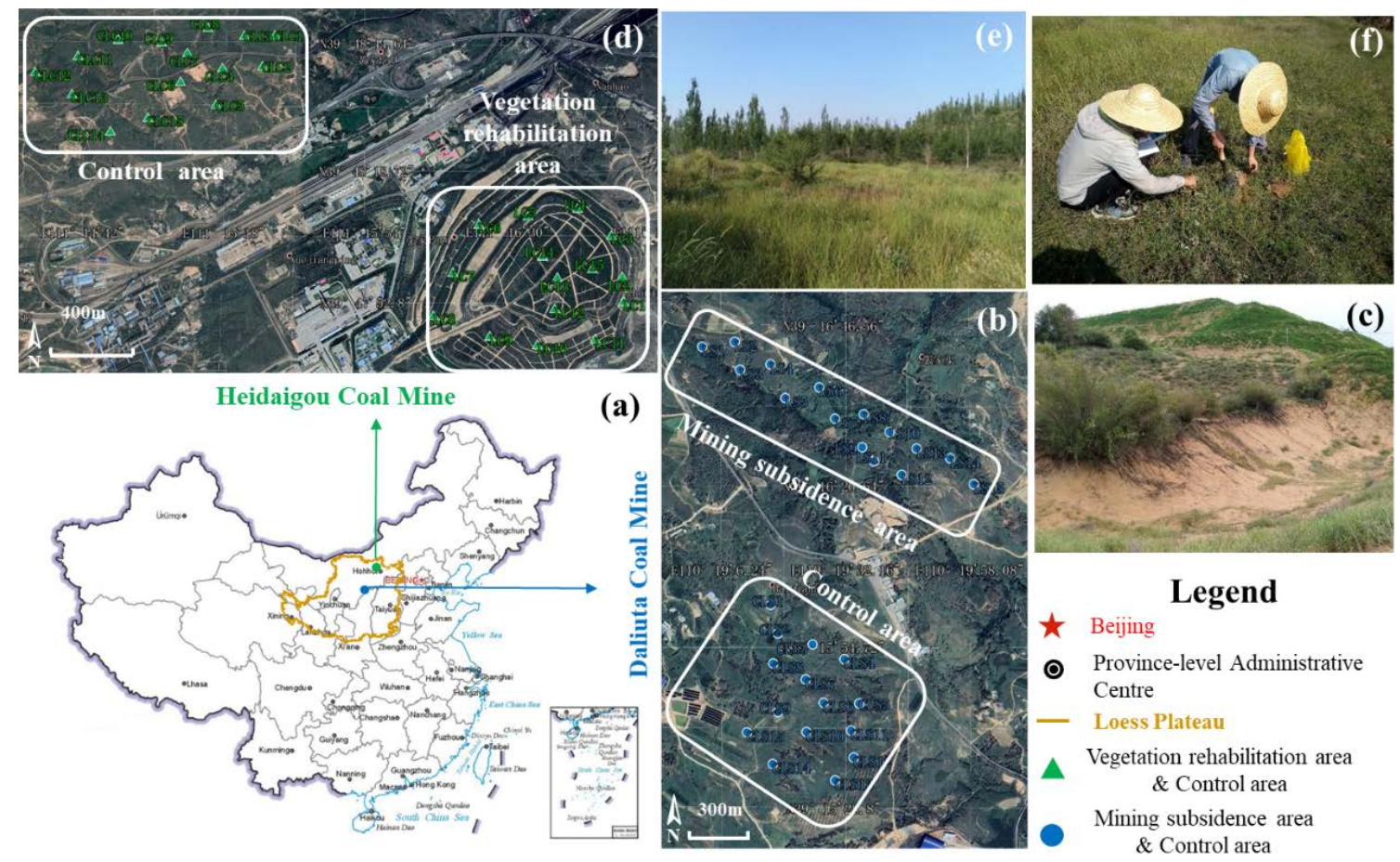

Figure 1. The study area and sampling sites of coal mining substance and vegetation rehabilitation. (a) Location of Daliuta and Heidaigou Coal Mines; (b) Sampling points of mining subsidence and control area in Daliuta Coal Mine; (c) Photograph of mining subsidence in Daliuta Coal Mine; (d) Sampling points of vegetation rehabilitation and control area in Heidaigou Coal Mine; (e) Photograph of vegetation rehabilitation in Heidaigou Coal Mine; (f) Photograph of soil sampling.

The Daliuta Coal Mine is located at $110^{\circ} 12^{\prime} \mathrm{E}-110^{\circ} 23^{\prime} \mathrm{E}$ and $39^{\circ} 13^{\prime} \mathrm{N}-39^{\circ} 22^{\prime} \mathrm{N}$, with a warm semi-arid continental climate and obvious seasonal changes (Figure 1b). The altitude is $1057-1334 \mathrm{~m}$. The average annual temperature is $8.6^{\circ} \mathrm{C}$, and annual precipitation is $290.4-410.3 \mathrm{~mm}$. The Daliuta Coal Mine was officially established in the year of 1996, with an original production capacity of 3.6 million tons/year, which has increased to 10.4 million tons/year currently. The underground mine goaf accounts for $70 \%$ of the total mining area. Long-term mining has led to a decline in the groundwater level, thickening of the surface dry sand layer, decrease in the soil moisture content, and frequent loss of 
vegetation, as shown in Figure $1 c$, and is a typical mining subsidence area in the Loess Plateau. The sampling site in this study was located in the southeast part of the Daliuta Mine. It belonged to the 52302 working face, a surface at which underground coal mining activities were carried out. The coal seam was shallowly buried, thick, and almost horizontal. The surface was covered by a thick, loose layer of soil. Long-arm mining and caving roof management were adopted with an advancing speed of $12 \mathrm{~m} \cdot \mathrm{d}^{-1}$. The mining pattern here was a typical high-strength mining mode with a super-large working face.

The Heidaigou Mine is located at $39^{\circ} 43^{\prime}-39^{\circ} 49^{\prime} \mathrm{N}$ and $111^{\circ} 13^{\prime}-111^{\circ} 20^{\prime} \mathrm{E}$, with a warm semi-arid continental climate and obvious seasonal changes (Figure 1d). The annual precipitation is $231.0-459.5 \mathrm{~mm}$, the annual average temperature is $7.2^{\circ} \mathrm{C}$, and the annual average evaporation is $2082.2 \mathrm{~mm}$, with an annual 3119.3 sunshine-hours. The typical vegetation of the Heidaigou Coal Mine is savanna in the temperate zone. The plants are low and scarce, with less than $30 \%$ coverage. The soil is slightly alkaline, infertile and aeolian sandy. The Heidaigou Coal Mine was operated in 1996, leading to serious land damage. The sampling sites were located in the northern fields with 16 years of vegetation rehabilitation and remote fields with no vegetation rehabilitation (Figure 1e).

\subsection{Soil Sample Acquirement and Analysis}

Fifteen samples for testing and 15 control samples were collected from each of the two mining regions between August 15 to 23, 2018 (Figure 1f). A total of 60 samples were collected. All sampling sites were selected with similar vegetation types, which were mainly covered by Stipa bungeana. The surface soil in the subsidence area of the Daliuta Mine was denoted by LS, and the control samples were denoted by CLS (Figure 1b). The surface soil in the vegetation rehabilitation area of the Heidaigou Mine was denoted by LR, and the control samples, acquired from land far away from the vegetation rehabilitation area, were denoted by CLR (Figure 1d). During the sampling process, about $1 \mathrm{~kg}$ of topsoil was randomly withdrawn at a depth of $0-20 \mathrm{~cm}$ using the five-point sampling method. These soil samples were packed and sealed in sterile polyethylene bags, frozen at $-20^{\circ} \mathrm{C}$ in a refrigerator and sent to the laboratory for treatment. A proportion of fresh soil samples were directly analyzed to learn the structure of soil bacterial communities. The other samples were naturally dried. Then, the gravels and residues from organisms were removed. The physicochemical properties of these samples were determined after screening with 2-mm sieves.

\subsection{Analysis of Soil Physicochemical Properties}

The moisture content, temperature, $\mathrm{pH}, \mathrm{EC}$, organic matter, ammonium nitrogen, nitrate nitrogen, available potassium and available phosphorus of soil samples were measured through the procedures mentioned henceforth [54]. The moisture content and temperature were measured using a fast determination instrument (TR-6, Shunkeda, Guangzhou, Guangdong Province, China). The $\mathrm{pH}$ and EC were measured by potentiometry (water: soil $=1$ : 2.5; DDS-307A, Leici Company, Shanghai, China). The organic matter content was determined through the potassium dichromate-colorimetry (Specord 210Plus, Jena Company, Jena, Germany). The ammonium nitrogen content was analyzed by ultraviolet spectrophotometry after potassium chloride extraction. The nitrate-nitrogen content was analyzed by ultraviolet spectrophotometry after calcium chloride extraction. The available phosphorus content was analyzed by molybdenum-antimony-scandium colorimetry after ammonium bicarbonate. Available potassium was determined by flame photometry after ammonium acetate extraction (FP640, Jingke, Shanghai, China).

\subsection{DNA Extraction, Purification, PCR Amplification, and 16SrRNA Sequencing}

DNA from 60 soil samples was extracted according to the instructions of FastDNA ${ }^{\text {TM }}$ SPIN kit (MP Biomedicals, Irvine, CA, USA), and the V4 and V5 regions of corresponding 16S rRNA in soil bacteria were PCR amplified using primers 515F(5'-GTGCCAGCMGCCGCGGTAA-3') and 907R(5'-CCGTCAATTCMTTTRAGTTT- $\left.3^{\prime}\right)$. The PCR amplification procedure was a follows: 
pre-denaturation at $98{ }^{\circ} \mathrm{C}(2 \mathrm{~min}) ; 25$ cycles of denaturation at $98{ }^{\circ} \mathrm{C}(15 \mathrm{~s})$, annealing at $55{ }^{\circ} \mathrm{C}(30$ s), extension at $72{ }^{\circ} \mathrm{C}(30 \mathrm{~s})$; extension at $72{ }^{\circ} \mathrm{C}(5 \mathrm{~min})$, and cooling to $10^{\circ} \mathrm{C}$. The products of PCR amplification were detected by $2 \%$ agarose gel electrophoresis. The target sequences were recovered with a gel recycling kit (Axygen, Corning, NY, USA). According to the preliminary electrophoresis quantitation results, the sequences recovered were quantified on a Microplate reader (BioTek, FLx800, Winooski, VT, USA), using Quant-iT PicoGreen dsDNA Assay Kit fluorescent reagent. The samples were mixed in equal proportion. The sequencing library of soil bacteria was prepared with the TruSeq Nano DNA LT Library Prep Kit (Illumina, San Diego, CA, USA). The constructed library was quantified by Qubit and Q-PCR and then sequenced (Shanghai Personal Biotechnology Co., Ltd., Shanghai, China) with HiSeq2500 PE2500 (Illumina, San Diego, CA, USA).

\subsection{Construction of Soil Bacterial Molecular Ecological Network}

The molecular ecological network of soil bacteria was constructed with 16S rRNA sequencing data, according to the theory of random matrix (RMT) [46,50,52]. Four networks were built with the 60 acquired samples, and 15 samples were involved in each network, which contained corresponding soil types. During the construction process, the OTUs (operational taxonomic units) with frequencies lower than $75 \%$ in the samples were abandoned, and the relative abundance values of the logarithms of OTU data $(\log 10)$ were transformed to calculate the Pearson correlation coefficients between OTUs to acquire similarity matrixes. With optimal similarity threshold values, an adjacency matrix was generated from the similarity matrix. The strength of the connection between each pair of nodes was coded with the adjacency matrix. The ecological community was predicted by analyzing the nearest distance distribution of the eigenvalues of the correlation matrix. The network construction and statistical analysis were performed by using the platform $\mathrm{http}: / /$ ieg4.rccc.ou.edu/mena. The molecular ecological network of soil bacteria after mining was visualized by the software Cytoscape 3.7.1 [55].

\subsection{Statistical Analysis and Processing}

The richness and diversity of soil bacterial communities were analyzed using Alpha diversity indexes at the galaxy platform (http//:mem.rcees.ac.cn.8080/). This was carried out by using the Chao1 estimator (https://mothur.org/wiki/chao/) and ACE estimator (https://mothur.org/wiki/ace/), reflecting the soil bacterial community richness, as well as using the Shannon diversity index (https: //mothur.org/wiki/shannon/) and the Simpson index (https://mothur.org/wiki/simpson/), representing the soil bacterial community diversity. The one-way analysis of variance (ANOVA) was carried out with the SPSS 20.0 software (IBM, Armonk, NY, USA). A redundancy analysis (RCA) was applied to characterize the interactions between soil environmental factors and bacterial communities with Canoco 4.5 for windows software. Mantel Test analysis was conducted with the R-project software (https://www.r-project.org/). The abundance plots of bacterial communities at different levels were obtained with the Origin 9.0 software (Origin Lab, Northampton, MA, USA).

\section{Results}

3.1. Effects of Ecological Processes on the Soil Physicochemical Characteristics in the Mining Subsidence and Vegetation Rehabilitation Areas

The ecological processes dominated by mining subsidence and vegetation rehabilitation exhibited remarkable differentiations on the soil physicochemical properties (Table 1). While the mining subsidence was inhibited, vegetation rehabilitation recovered the soil physicochemical properties after disturbance due to coal mining.

The mining subsidence had a negative impact on soil physicochemical properties. In the mining subsidence area, soil temperature (ST), organic matter $(\mathrm{OM})$, available phosphorus (AP), available potassium (AK), ammonium nitrogen (AN), and nitrate nitrogen $(\mathrm{NN})$ decreased by $5.1{ }^{\circ} \mathrm{C}(P<0.01)$, $42.2 \%(P<0.01), 20 \mathrm{mg} \cdot \mathrm{kg}^{-1}(P<0.05), 20 \mathrm{mg} \cdot \mathrm{kg}^{-1}(P<0.05), 0.2 \mathrm{mg} \cdot \mathrm{kg}^{-1}(P<0.05)$, and $0.2 \mathrm{mg} \cdot \mathrm{kg}^{-1}$ 
$(P>0.05)$, respectively. Concomitantly, soil water content (SWC), $\mathrm{pH}$, and electrical conductivity (EC) increased by nearly $33.1 \%(P<0.05), 0.2(P>0.05)$, and $0.3 \mathrm{~ms} \cdot \mathrm{cm}^{-3}(P>0.05)$, respectively. Mining subsidence had caused a decreasing tendency of $\mathrm{ST}, \mathrm{OM}, \mathrm{AP}, \mathrm{AK}, \mathrm{AN}$, and NN, but an increasing trend of SWC, $\mathrm{pH}$, and EC.

Table 1. Changes of soil physicochemical properties after mining substance and vegetation rehabilitation.

\begin{tabular}{lllll}
\hline \multirow{2}{*}{ Soil Physicochemical Properties } & \multicolumn{2}{l}{ Mining Substance } & \multicolumn{2}{l}{ Vegetation Rehabilitation } \\
\cline { 2 - 5 } & LS & CLS & LR & CLR \\
\hline $\mathrm{SWC} /(\%)$ & $10.01 \pm 3.21^{*}$ & $7.52 \pm 1.74$ & $13.35 \pm 3.64^{*}$ & $10.67 \pm 2.00$ \\
$\mathrm{ST} /\left({ }^{\circ} \mathrm{C}\right)$ & $26.94 \pm 1.65^{* *}$ & $31.00 \pm 4.37$ & $26.15 \pm 3.54^{* * *}$ & $31.32 \pm 3.62$ \\
$\mathrm{pH}$ & $7.71 \pm 0.44$ & $7.48 \pm 0.42$ & $8.56 \pm 0.27^{* * *}$ & $7.74 \pm 0.45$ \\
$\mathrm{EC} /\left(\mathrm{ms} \cdot \mathrm{cm}^{-3}\right)$ & $5.76 \pm 1.12$ & $5.41 \pm 1.81$ & $15.87 \pm 3.49^{*}$ & $12.35 \pm 3.43$ \\
$\mathrm{OM} /\left(\mathrm{g} \cdot \mathrm{kg}^{-1}\right)$ & $0.95 \pm 0.63^{* *}$ & $1.65 \pm 0.51$ & $1.86 \pm 0.45^{* *}$ & $1.46 \pm 0.23$ \\
$\mathrm{AP} /\left(\mathrm{mg} \cdot \mathrm{kg}^{-1}\right)$ & $123.14 \pm 22.43^{*}$ & $145.14 \pm 22.66$ & $130.48 \pm 31.53^{*}$ & $96.13 \pm 38.13$ \\
$\mathrm{AK} /\left(\mathrm{mg} \cdot \mathrm{kg}^{-1}\right)$ & $99.26 \pm 8.38^{* * *}$ & $108.89 \pm 4.21$ & $74.94 \pm 15.74^{* *}$ & $51.25 \pm 17.07$ \\
$\mathrm{NN} /\left(\mathrm{mg} \cdot \mathrm{kg}^{-1}\right)$ & $0.29 \pm 0.11$ & $0.31 \pm 0.13$ & $0.51 \pm 0.24^{* *}$ & $0.29 \pm 0.06$ \\
$\mathrm{AN} /\left(\mathrm{mg} \cdot \mathrm{kg}^{-1}\right)$ & $0.42 \pm 0.17^{*}$ & $0.60 \pm 0.19$ & $1.22 \pm 0.18^{*}$ & $0.98 \pm 0.38$ \\
\hline
\end{tabular}

Note: ${ }^{*}$ represents the significance of the disturbance zone and the control T-test, ${ }^{*}$ mean significant difference at $5 \%$, ${ }^{* *}$ mean significant difference at $1 \%,{ }^{* * *}$ mean extremely significant difference at $1 \%$. SWC, soil water content; ST, soil temperature; $\mathrm{OM}$, soil organic matter; $\mathrm{AP}$, available phosphorus; $\mathrm{AK}$, available potassium; $\mathrm{NN}$, nitrate-nitrogen; $\mathrm{AN}$, ammonium nitrogen. The abbreviations in the text have the same meaning.

The vegetation rehabilitation exhibited positive influence on soil physicochemical properties. In the vegetation rehabilitation area, $\mathrm{SWC}, \mathrm{pH}, \mathrm{EC}, \mathrm{OM}, \mathrm{AP}, \mathrm{AK}, \mathrm{NN}$, and $\mathrm{AN}$ increased by $25.1 \%(P<$ 0.05), $0.8(P<0.001), 3.5 \mathrm{~ms} \cdot \mathrm{cm}^{-3}(P<0.05), 0.4 \mathrm{~g} \cdot \mathrm{kg}^{-1}(P<0.01), 30 \mathrm{mg} \cdot \mathrm{kg}^{-1}(P<0.01), 20 \mathrm{mg} \cdot \mathrm{kg}^{-1}$ $(P<0.01), 0.2 \mathrm{mg} \cdot \mathrm{kg}^{-1}(P<0.001)$, and $0.2 \mathrm{mg} \cdot \mathrm{kg}^{-1}(P<0.05)$, respectively. However, ST declined significantly by $5.2^{\circ} \mathrm{C}(P<0.001)$. Thus, vegetation rehabilitation initiated a recovery trend of SWC, $\mathrm{pH}, \mathrm{EC}, \mathrm{OM}, \mathrm{AP}, \mathrm{AK}, \mathrm{NN}$, and $\mathrm{AN}$, but a decline in $\mathrm{ST}$.

\subsection{Effects of Ecological Processes on the Soil Bacterial Communities in Mining Subsidence and Vegetation Rehabilitation Areas}

\subsubsection{Effects of Mining Subsidence and Vegetation Rehabilitation on the Alpha Diversities of Soil} Bacteria

The impact of mining subsidence and vegetation rehabilitation on the soil bacterial alpha diversities has been shown in Figure 2. The results show that the average Chao1 and ACE indices in the mining subsidence area of the Daliuta Coal Mine largely decreased by $20 \%(P<0.01)$ compared to those in the control group. The Shannon and Simpson indices were slightly lower than those in the control group $(P<0.05)$. These characteristics indicate that the mining subsidence reduced the abundance and homogeneity of soil bacterial communities. The Chao1 and ACE indices in the vegetation rehabilitation area of the Heidaigou Coal Mine were 1.63 and 1.67 times of those in the control group, respectively, with significant differences $(P<0.001)$. These features indicate that the vegetation rehabilitation led to a significant increase in the diversity of the soil bacterial community structure.

\subsubsection{Effects of Mining Subsidence and Vegetation Rehabilitation on the Soil Bacterial Composition}

The ecological processes dominated by mining subsidence and vegetation rehabilitation altered the compositions of soil bacterial communities (Figure 3). As shown in Figure 3a, the primary phyla in the soil sample of the mining subsidence area and control area of the Daliuta Coal Mine were consistent. The primary phyla, whose relative abundance accounted for more than $90 \%$ of the overall abundance, included Actinobacteria, Proteobacteria, Acidobacteria, Chloroflexi, Gemmatimonadetes, Planctomycetes, Armatimonadetes, and Bacteroidetes. However, the relative abundance of individual phylum appeared to have obviously changed. The relative abundance values of Proteobacteria, Chloroflexi, Gemmatimonadetes, 
and Bacteroidetes were elevated in the mining subsidence area, particularly, that of Chloroflexi, which increased to $25.18 \%$ (21.86\% in the control group). The relative abundance of Actinobacteria, Acidobacteria, and Planctomycetes decreased slightly, particularly that of Planctomycetes, which decreased to $4.45 \%$ (7.97\% in the control group). These changes indicate that the soil bacterial communities adapted according to the mining subsidence environment.
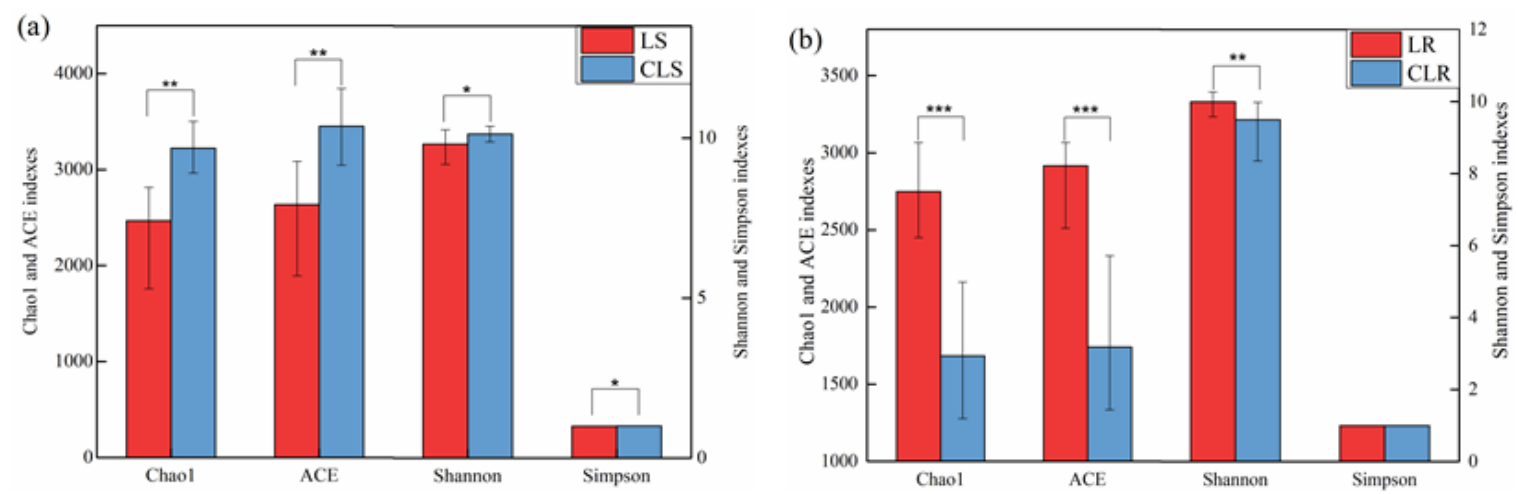

Figure 2. Changes in soil bacterial alpha diversities in mining subsidence area and vegetation rehabilitation area. $(\mathbf{a}, \mathbf{b})$ are the index of alpha diversity in Daliuta Coal Mine and Heidaigou Coal Mine, respectively. LS and CLS represent samples from the mining subsidence area and control area in Daliuta Coal Mine, respectively. LR and CLR represent samples from vegetation rehabilitation area and control area in Heidaigou Coal Mine, respectively. ${ }^{*} p<0.5,{ }^{* *} p<0.01,{ }^{* * *} p<0.001$

(a)

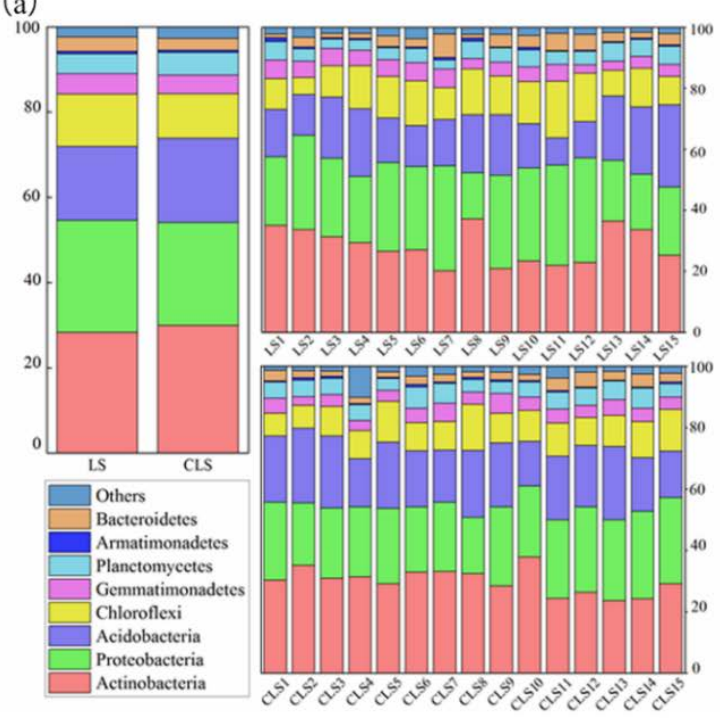

(b)

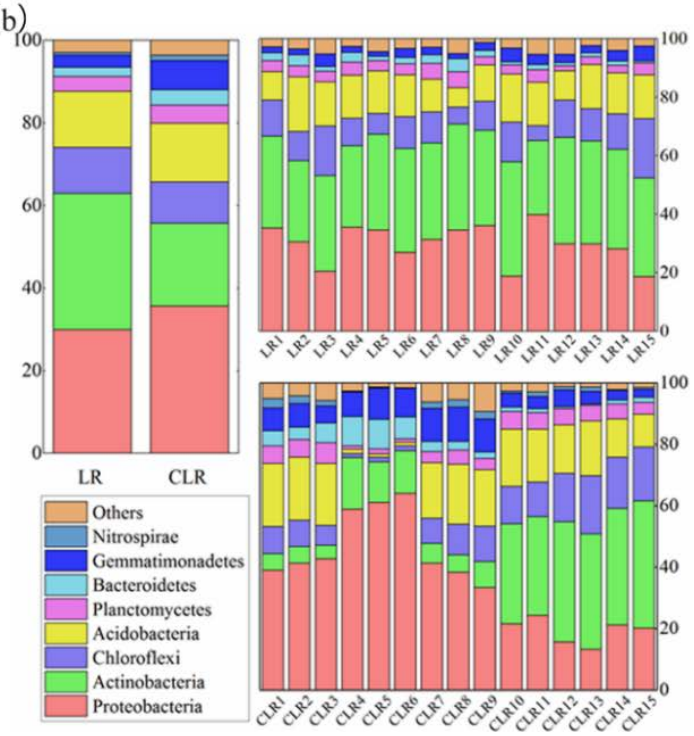

Figure 3. Bar diagram to represent the analysis at phylum level in mining subsidence area (a) and vegetation rehabilitation area $(\mathbf{b})$.

The primary phyla in the soil sample of the vegetation rehabilitation area and control area of the Heidaigou Coal Mine were similar (Figure 3b). The primary phyla, whose relative abundance accounted for greater than 90\%, included Proteobacteria, Actinobacteria, Chloroflexi, Acidobacteria, Planctomycetes, Bacteroidetes, Gemmatimonadetes, and Nitrospira. Among them, the Actinobacteria preferred the soil environment in the vegetation rehabilitation area, of which the relative abundance was higher than that in the control group by $64.0 \%$. However, the relative abundance values of Proteobacteria and Gemmatimonadetes were lower than those in the control group. The relative abundance of Nitrospira was even as low as $<1 \%$. These changes demonstrated that the soil bacterial communities adapted to the vegetation rehabilitation environment. 
3.3. Effect of Ecological Process on the Soil Bacterial Molecular Ecological Network in Mining Subsidence Area and Vegetation Rehabilitation Area

3.3.1. Effect of Mining Subsidence and Vegetation Rehabilitation on Topological Properties of Soil Bacterial Molecular Ecological Networks

The specific topological properties of soil bacterial molecular ecological networks in mining subsidence and vegetation rehabilitation are mentioned in Table 2. According to the construction of molecular ecological networks, the OTUs with frequencies higher than $70 \%$ were adopted as the input items. The similarity thresholds for mining subsidence and vegetation rehabilitation areas were set to be 0.81 and 0.84 , respectively. The average connectivity, average path length, average aggregation coefficient and modularity values of both constructed networks were greater than those of random networks, indicating that these networks were reliable. The number of connection lines in the subsidence area was greater than that in the control group, indicating the enhanced complexity in the molecular ecological network after mining subsidence. The average clustering coefficient, average path distance and density in the subsidence area were higher than those in the control group, indicating that the increase in the connection strength of each node and the network nodes were closer after the subsidence. However, the modularity index was smaller than that of the control group after the subsidence, indicating that the resistance of soil bacterial communities to external changes was weakened by subsidence. Compared to the control group, the number of nodes in the molecular ecological network of the vegetation rehabilitation area increased, although, the number of connection lines decreased, indicating that the community structure tended to be diversified, even when the interconnections were weakened.

Table 2. Topological properties of soil bacterial molecular ecological networks in mining subsidence and vegetation rehabilitation.

\begin{tabular}{|c|c|c|c|c|}
\hline \multirow{2}{*}{ Topological Parameters } & \multicolumn{2}{|c|}{ Mining Subsidence } & \multicolumn{2}{|c|}{ Vegetation Rehabilitation } \\
\hline & LS & CLS & LS & CLS \\
\hline Similarity threshold ${ }^{1}$ & 0.81 & 0.81 & 0.84 & 0.84 \\
\hline Nodes $^{2}$ & 245 & 171 & 114 & 92 \\
\hline Links $^{3}$ & 514 & 162 & 148 & 320 \\
\hline $\operatorname{AvgK} 4$ & 4.196 & 1.895 & 2.596 & 6.957 \\
\hline $\operatorname{AvgCC}^{5}$ & 0.244 & 0.168 & 0.213 & 0.414 \\
\hline AvgPD 6 & 6.007 & 5.333 & 6.241 & 4.983 \\
\hline Density ${ }^{7}$ & 0.017 & 0.011 & 0.023 & 0.076 \\
\hline Connectivity ${ }^{8}$ & 0.647 & 0.087 & 0.295 & 0.957 \\
\hline Module $^{9}$ & 29 & 40 & 22 & 4 \\
\hline Modularity 10 & 0.652 & 0.915 & 0.777 & 0.483 \\
\hline $\mathrm{R}_{\text {square }}{ }^{11}$ & 0.921 & 0.888 & 0.939 & 0.700 \\
\hline
\end{tabular}

Note: ${ }^{1}$ Similarity threshold: the soil bacterial molecular ecological network of the experimental group and the control group were built under the same threshold when $P<0.05 .{ }^{2}$ Nodes: the numbers formed by the network construction. ${ }^{3}$ Links: the number of connections between nodes. ${ }^{4}$ AvgK: Average connectivity, which presented the complexity of networks. ${ }^{5}$ AvgCC: Average clustering coefficient, which was used to determine the extent of the module structure present in different networks. ${ }^{6}$ AvgPD: Average path distance, or the average distance between two nodes. ${ }^{7}$ Density: the complexity of the network. ${ }^{8}$ Connectivity: node degree, was used to describe the topological property of a node in a network. ${ }^{9}$ Module: a group of OTUs that had high connections among themselves, but fewer connections outside the group in the network. ${ }^{10}$ Modularity: a network that could be naturally divided into communities or modules. ${ }^{11} \mathrm{R}$ square: the credibility of scale-free networks. More information about these parameters is given in Deng et al. [46].

The modules and connectivity of molecular ecological networks in the mining subsidence area and vegetation rehabilitation area are shown in Figure 4. The connectivity within or between modules of a molecular ecological network can reflect the roles played by different OTUs. The nodes with $\mathrm{Zi} \geq 2.5$ or $\mathrm{Pi} \geq 0.62$ are generally considered as crucial species [46]. The ecological network of the subsidence area contained three connection nodes and one module, while that of the control group had 
only peripheral nodes. The ecological network of the vegetation rehabilitation area contained only one module, while that of the control group contained two modules. Among the key species, the nodes with the highest connectivity were located above the dotted line and towards the right side. The key species with the highest connectivity in the mining subsidence area is Proteobacteria while those in the vegetation rehabilitation area and the control group are Proteobacteria and Actinobacteria, respectively.

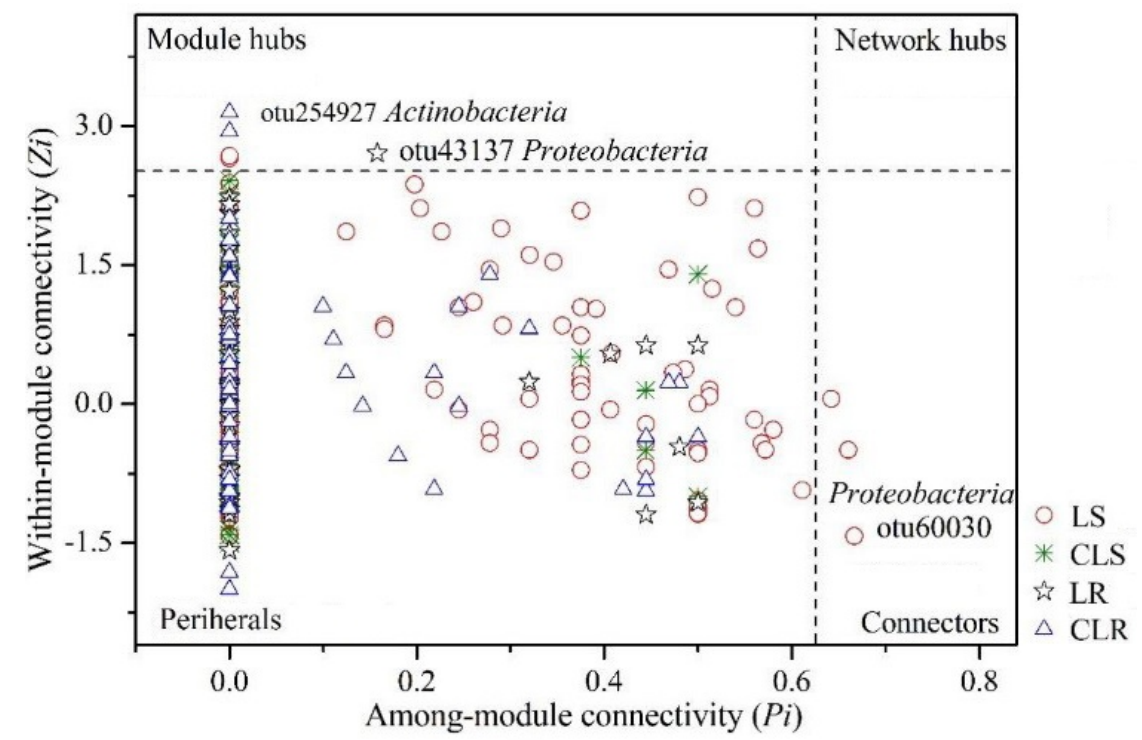

Figure 4. $\mathrm{Zi}-\mathrm{Pi}$ plot of molecular ecological networks in mining subsidence area and vegetation rehabilitation area.

3.3.2. Assessment of the Effect of Mining Subsidence and Vegetation Rehabilitation on Soil Bacterial Molecular Ecological Networks

Based on the sequencing results of soil bacteria, four visualized molecular ecological networks were constructed to show the relationships between species in both ecological processes (Figure 5). Figure 5a shows that after mining subsidence, significantly higher connections between the nodes were observed than those in the control group (Figure 5c) and that the nodes tended to cooperate with each other (blue). Figure 5b,d show the decline in the number of modules in the molecular ecological network of the subsidence area, although these modules exhibited closer connections, indicating that the soil bacteria made changes to adapt to the nutrient loss in the adverse habitat caused by subsidence and that these soil bacterial communities cooperated with each other. The connections between nodes in the network of vegetation rehabilitation areas were significantly lower than those in the network of the control group, as shown in Figure 5e,g, respectively. In addition, the number of network modules in the network of the vegetation rehabilitation area was greater than that in the control group. The relationships between modules appeared to change from competition (Figure 5h) to cooperation (Figure 5f). The network modularity index of the vegetation rehabilitation area was significantly higher than that of the control group, indicating that the resistance characteristics of bacteria to external changes were significantly enhanced, and that the vegetation rehabilitation had a positive impact on the bacterial communities. 


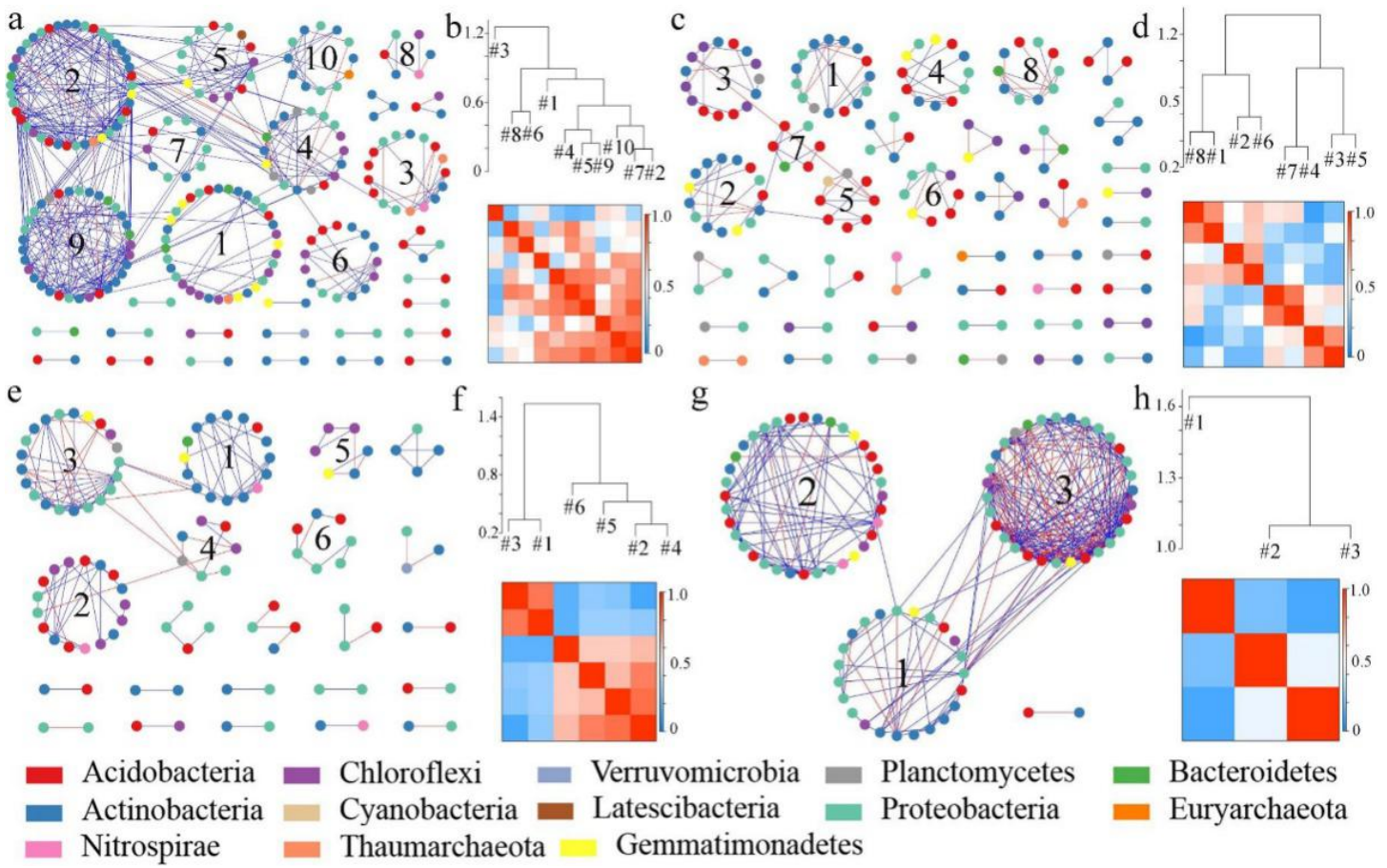

Figure 5. Soil bacterial molecular ecological networks and module eigengene hierarchy structure in a mining subsidence area and vegetation rehabilitation area. $(\mathbf{a}, \mathbf{c})$ represent the soil bacterial molecular ecological network in the mining subsidence area and its control. (e,g) represent the soil bacterial molecular ecological network in vegetation rehabilitation area and its control. (b,d) represent the soil bacterial modular eigengene hierarchy structure in mining subsidence area and its control. (f,h) represent soil bacterial modular eigengene hierarchy structure in the vegetation rehabilitation area and its control. The connecting line represents the interaction of the target level on phylum, with blue representing positive and red representing negative interaction.

3.4. Effects of Ecological Processes on Interactions between Soil Bacterial Communities and Physicochemical Properties in the Mining Subsidence and Vegetation Rehabilitation Areas

3.4.1. Interactions between Soil Bacterial Phyla and Physicochemical Properties in the Mining Subsidence and Vegetation Rehabilitation Areas

At the level of phylum $>1 \%$, RDA analysis of soil bacterial communities and environmental factors was carried out with the subsidence area of the Daliuta Coal Mine, vegetation rehabilitation area of the Heidaigou Coal Mine, and their corresponding control groups as the research targets. The results are shown in Figure 6.

For the mining subsidence area and control group of the Daliuta Coal Mine, the explanation degrees of RDA1 and RDA2 axes of soil bacterial communities for the results reached $26.63 \%$ and $10.62 \%$ at the level of phyla, respectively. However, all the sampling points of the mining subsidence area and the control group did not clearly separate into groups. Instead, they intertwine with each other. As per the RDA analysis results of soil physicochemical properties (Figure 6a), SWC positively correlated after the mining subsidence, while the sampling points of the control group positively correlated with ST, AP and AN. OM showed similar correlations in the mining subsidence area and the control group. The RDA analysis results of all phyla in samples (Figure $6 \mathrm{~b}$ ) indicate that the soil bacteria in the subsidence area were closely related to the phyla, including Latescibacteria, Chloroflexi, Bacteroidetes, Proteobacteria, and Firmicutes, while the soil bacteria in the control group were closely related to Cyanobacteria. Considering the phyla and physicochemical properties of sampling points (Figure 6c), $\mathrm{pH}$ and NN closely positively correlated with Acidobacteria, but correlated negatively with Firmicutes and Verrucomicrobia in a highly similar manner; OM correlated negatively with Gemmatimonadetes; 
EC correlated negatively with Chloroflexi and Proteobacteria; ST and AN correlated positively with Armatimonadetes; SWC correlated negatively with Armatimonadetes; and AK correlated positively with Proteobacteria.
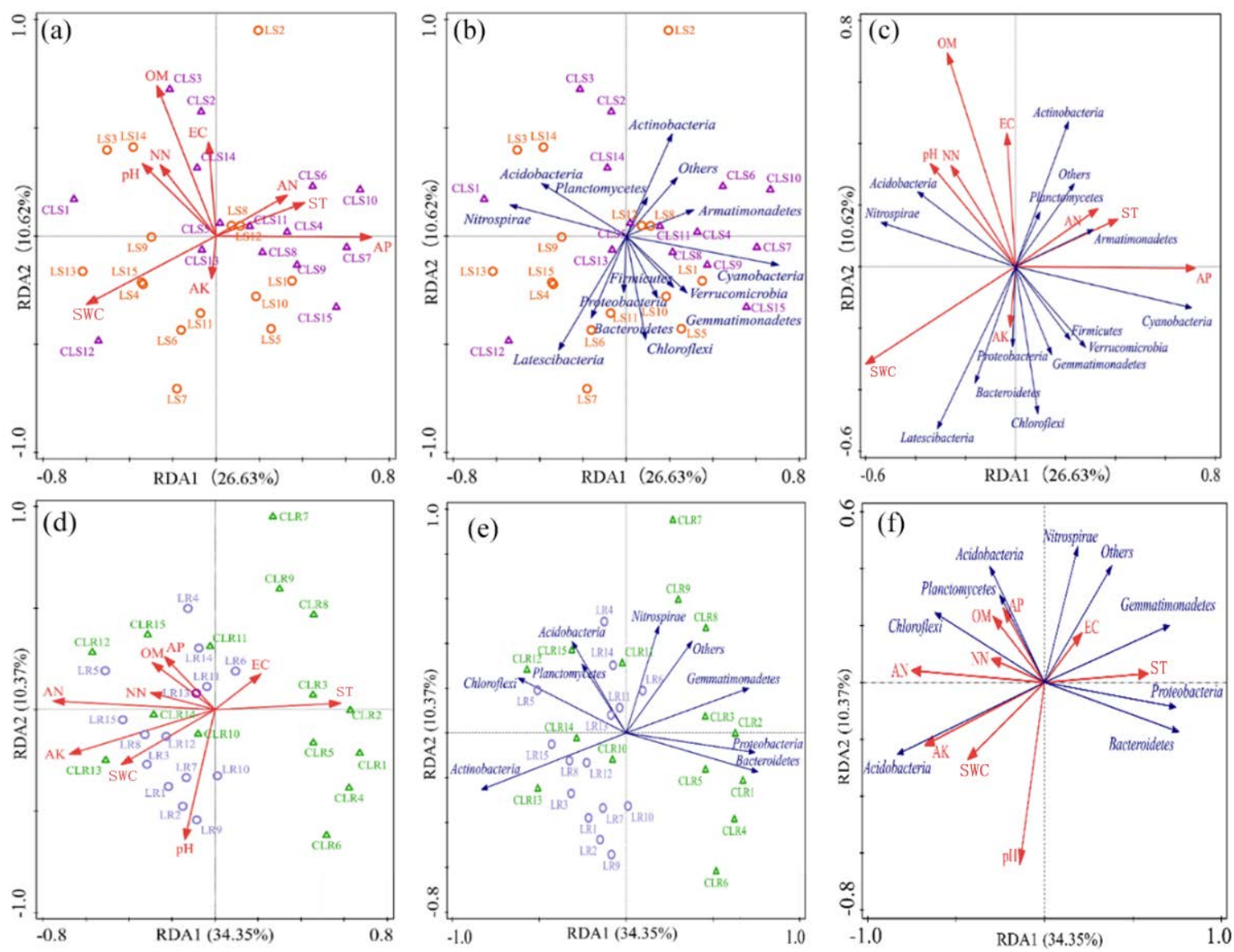

Figure 6. RDA analysis of samples and environmental factors (a,d), samples and major phyla (b,e), and environmental factors and major phyla $(\mathbf{c}, \mathbf{f})$. $(\mathbf{a}-\mathbf{c})$ represent RDA analysis of mining subsidence area and its control area in the Daliuta Coal Mine. $(\mathbf{d}-\mathbf{f})$ represent RDA analysis of vegetation rehabilitation area and its control area in the Heidaigou Coal Mine.

The explanation degrees of RDA1 and RDA2 axes of soil bacterial communities for the vegetation rehabilitation and control group of the Heidaigou Coal Mine for the results reached 34.35\% and 10.37\% at the level of phylum, respectively. The sampling points of the vegetation rehabilitation area showed an obvious trend of clustering, while those of the control group were relatively scattered. According to the results of RDA analysis of soil physicochemical properties (Figure 6d), the vegetation rehabilitation area positively correlated with $\mathrm{pH}, \mathrm{SWC}, \mathrm{OM}, \mathrm{AP}, \mathrm{AK}, \mathrm{NN}$ and $\mathrm{AN}$, but was correlated negatively with EC and ST. In contrast, the sampling points of the control group had no evident relationship with these physicochemical properties. According to the RDA analysis of all the phyla and samples (Figure 6e), the soil bacteria in the vegetation rehabilitation area closely correlated with Actinobacteria, Chloroflexi, Planctomycetes, Acidobacteria, and Nitrospira, while the control group closely correlated with Gemmatimonadetes, Proteobacteria, and Bacteroidetes. Considering the phyla and physicochemical properties of the sampling points (Figure 6f), AK closely correlated positively with Actinobacteria, but negatively with Gemmatimonadetes; NN correlated closely positively with Chloroflexi, but negatively with Bacteroidetes; OM and AP closely positively correlated to Planctomycetes and Acidobacteria; ST closely positively related to Proteobacteria and Bacteroidetes; while EC closely positively correlated to other phyla except for Actinobacteria, which was negatively related. 
These results thus show that the mining subsidence area of the Daliuta Coal Mine and the control group showed differences at the phylum level and in the physicochemical properties. The vegetation rehabilitation area and the control group of the Heidaigou Coal Mine exhibited similar characteristics. Mining subsidence and vegetation rehabilitation changed the distribution and physicochemical properties of the soil bacterial community structure.

3.4.2. Interaction between OTUs and Physicochemical Properties in Mining Subsidence and Vegetation Rehabilitation Areas

The Mantel test results of OTU level of soil bacteria and environmental factors show that both ecological processes significantly changed the physical and chemical properties of soil, further affecting the diversity characteristics of soil bacterial communities (Table 3). However, the dominant environmental factors changing soil bacterial communities during different ecological processes varied. The OTU levels of soil bacteria had significantly positive correlations with NN in the subsidence area of the Daliuta Mine, but the OTU levels had no obvious correlation with other physicochemical properties, indicating that the loss of $\mathrm{NN}$ due to subsidence was an important driving force for the evolution of the bacterial community structure. There was a variation in dominant environmental factors for the soil bacteria in the vegetation rehabilitation area of Heidaigou Mine. The OTU levels of soil bacteria had significant correlations with ST, AP, AK, NN and AN. Although the nutrients in the soil (AP and $\mathrm{NN}$ ) were still the dominant environmental factors for the development of bacterial communities, after vegetation rehabilitation, the coverage of plants on the surface increased, which significantly changed the ST and gas emissions. When the effect of environmental factors on the bacteria weakened, the cooperation between bacteria increased, resulting in a significant improvement in the stability of the soil environment.

Table 3. Mantel Test of the soil bacterial community, in terms of OTU level and environmental factors.

\begin{tabular}{lllll}
\hline \multirow{2}{*}{ Soil Physicochemical Properties } & \multicolumn{2}{l}{ Mining Substance } & \multicolumn{2}{l}{ Vegetation Rehabilitation } \\
\cline { 2 - 5 } & LS & CLS & LR & CLR \\
\hline $\mathrm{SWC} /(\%)$ & -0.0075 & 0.0197 & -0.00365 & -0.0282 \\
$\mathrm{ST} /\left({ }^{\circ} \mathrm{C}\right)$ & -0.0253 & 0.0059 & -0.0227 & $\mathbf{0 . 0 8 7 5}$ \\
$\mathrm{pH}$ & -0.0229 & -0.019 & 0.0309 & 0.0023 \\
$\mathrm{EC} /\left(\mathrm{ms} \cdot \mathrm{cm}^{-3}\right)$ & -0.0083 & -0.0727 & 0.02148 & -0.0257 \\
$\mathrm{OM} /\left(\mathrm{g} \cdot \mathrm{kg}^{-1}\right)$ & -0.0692 & -0.0651 & -0.05059 & 0.0376 \\
$\mathrm{AP} /\left(\mathrm{mg} \cdot \mathrm{kg}^{-1}\right)$ & -0.0671 & -0.0153 & $\mathbf{0 . 1 7 5}$ & 0.0582 \\
$\mathrm{AK} /\left(\mathrm{mg} \cdot \mathrm{kg}^{-1}\right)$ & -0.0092 & 0.0116 & -0.0133 & $\mathbf{0 . 0 8 2 3 ^ { * }}$ \\
$\mathrm{NN} /\left(\mathrm{mg} \cdot \mathrm{kg}^{-1}\right)$ & $\mathbf{0 . 1 0 3 2}$ & -0.0707 & $\mathbf{0 . 1 5 4 3}$ & -0.033 \\
$\mathrm{AN} /\left(\mathrm{mg} \cdot \mathrm{kg}^{-1}\right)$ & -0.0329 & 0.0041 & -0.004332 & $\mathbf{0 . 1 2 2 *}$ \\
\hline
\end{tabular}

Note: * mean significant difference at $5 \%{ }^{* *}$ mean significant difference at $1 \%$. All significant points are highlighted in bold.

3.4.3. Interactions between Soil Bacterial Genera and Physicochemical Properties in the Mining Subsidence and Vegetation Rehabilitation Areas

For a further understanding of the interactions between soil bacterial species and environmental factors, the environmental factors were set as network nodes, and the top 50 genera of soil microorganisms in the mining subsidence area and the control group of the Daliuta Coal Mine were extracted to construct a network for the comparison of the connections between environmental factors and microorganisms, based on the RMT theory. The radial distribution results with Variibacter as the center of the network are shown in Figure 7a. The number of connections between nodes and strength of connections between ST and AN were the greatest and strongest, followed by those of $\mathrm{pH}$, $\mathrm{EC}$, and NN. The nodes of AN, $\mathrm{pH}$ and ST were also relatively strong. The connections between EC and ST nodes and other nodes were the closest. The connections between OM nodes and adjacent nodes were the strongest. The connections between soil physicochemical properties and soil bacterial species 
showed predominantly negative correlations in the interactions in this network. Additionally, as per Figure 7a, ST, pH, EC, NN and AN were directly and closely related to the selected strain Variibacter. Variibacter related negatively to $\mathrm{pH}, \mathrm{EC}$, and NN, but positively to ST and AN. Therefore, Variibacter could serve as the indicator strain for evaluating soil quality improvement after the subsidence in the Daliuta Coal Mine of the Loess Plateau.

(a)

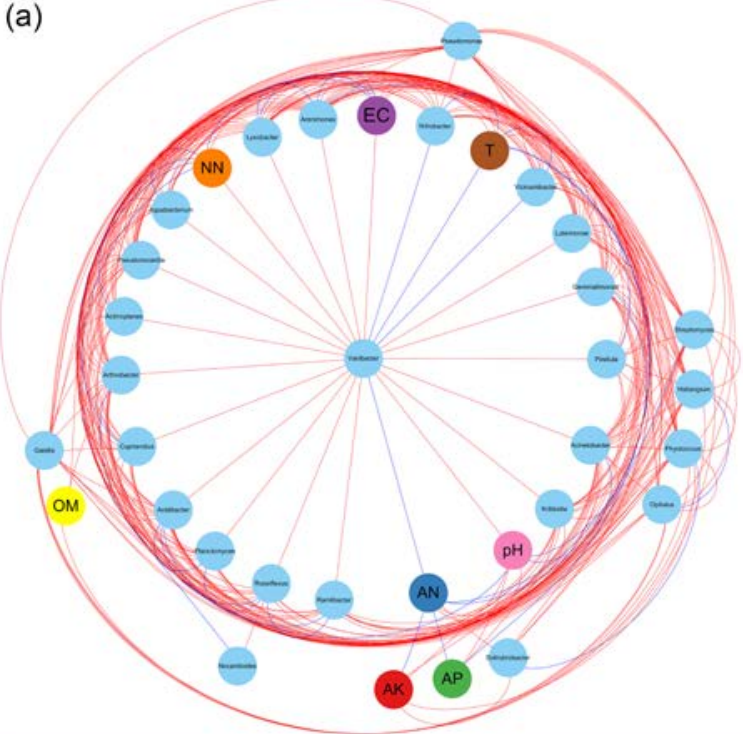

\begin{tabular}{lccccc} 
& \multicolumn{6}{c}{ node.degree node.betw } & node.stress & node.evcent & Clustering.Coefficient \\
ST & 8 & 7.93 & 34 & 0.05 & 0.43 \\
AN & 8 & 8.71 & 43 & 0.04 & 0.32 \\
pH & 7 & 6.81 & 41 & 0.04 & 0.38 \\
EC & 7 & 1.71 & 11 & 0.06 & 0.67 \\
NN & 7 & 4.04 & 21 & 0.04 & 0.33 \\
AK & 5 & 1.61 & 6 & 0.03 & 0.5 \\
AP & 4 & 0.7 & 3 & 0.02 & 0.5 \\
OM & 3 & 0 & 0 & 0.03 & 1
\end{tabular}

(b)

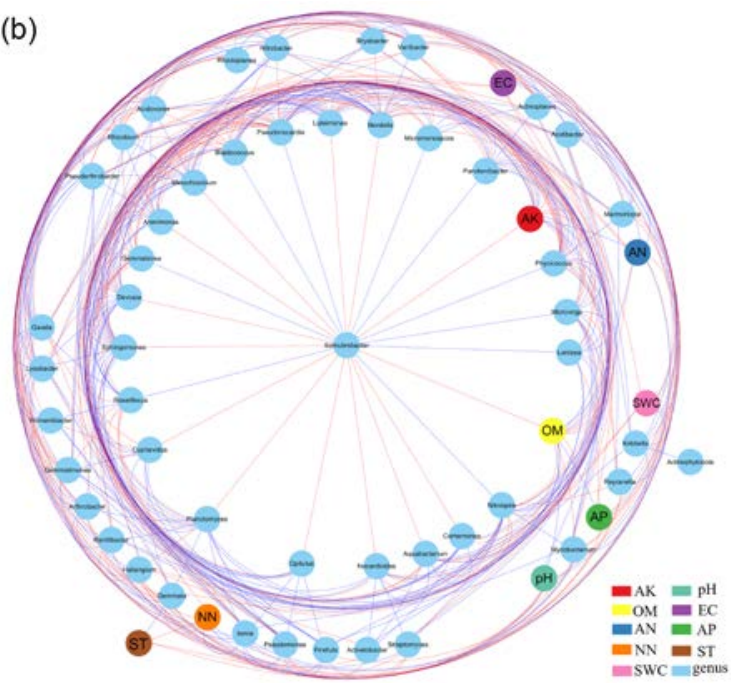

node.degree node.betw node.stress node.evcent Clustering.Coefficient

$\begin{array}{cccccc}\text { AK } & 17 & 25.78 & 177 & 0.15 & 0.47 \\ \text { OM } & 15 & 38.57 & 195 & 0.1 & 0.35 \\ \text { AN } & 10 & 10.7 & 73 & 0.07 & 0.47 \\ \text { NN } & 9 & 19.51 & 101 & 0.05 & 0.22 \\ \text { SWC } & 8 & 9.75 & 45 & 0.05 & 0.36 \\ \text { pH } & 8 & 14.05 & 73 & 0.04 & 0.32 \\ \text { EC } & 8 & 10.02 & 52 & 0.06 & 0.29 \\ \text { AP } & 7 & 7.83 & 34 & 0.04 & 0.14 \\ \text { ST } & 4 & 1.95 & 6 & 0.01 & 0.5\end{array}$

Figure 7. Radial layout plot between different genera and soil physicochemical properties in mining subsidence area (a) and vegetation rehabilitation area (b). node.degree: the topological property of a node in a network. node.betw: betweenness, the ratio of paths that pass through the node, which serves as a broker when it is high. node.stress: the number of geodesic paths that pass through one node. node.evcent: the degree of a central node that is connected to other central nodes. Clustering.Coefficient: hierarchical properties of networks, describing how well a node is connected with its neighbors. More detailed information can be found in Deng et al. [46].

Likewise, the environmental factors were set as network nodes, and the top 50 genera of soil bacteria in the vegetation rehabilitation area and the control group of the Heidaigou Coal Mine were extracted to construct a network based on the RMT theory for the comparison of the connections between environmental factors and microorganisms. The radial distribution results with Solirubrobacter as the center of the network are shown in Figure $7 \mathrm{~b}$. The number of connections between nodes and the strength of connections between $\mathrm{AK}$ and $\mathrm{OM}$ were the greatest and strongest, followed by those between $\mathrm{AN}, \mathrm{NN}, \mathrm{SWC}, \mathrm{pH}$, and EC. The connection between ST and bacterial communities were the least and the connections between soil physicochemical properties and soil microbial species showed primarily negative correlations between interactions in this network. In addition, OM and AK were directly and closely related to Solirubrobacter, showing negative correlations (Figure $7 \mathrm{~b}$ ). The remaining physicochemical properties were indirectly related to the strain. Hence, Solirubrobacter could serve as the indicator strain for evaluating soil quality improvement in the Heidaigou Coal Mine of the Loess Plateau. 


\section{Discussion}

\subsection{The Response of Ecological Processes to Mining Subsidence and Vegetation Rehabilitation in the Loess} Plateau

Mining subsidence and vegetation rehabilitation are two important ecological processes in the entire life of coal mining and the most important factors influencing the local ecological environment $[7,8,10,43]$. The mining subsidence caused by coal mining has always been a global problem $[7,56,57]$. The changes in surface morphology increase the risks of soil and water loss, reduce the vegetation coverage and significantly interfere with the soil ecological environment [13,22,58-61]. Vegetation rehabilitation is an important measure of remedial engineering, that aims to increase vegetation coverage, reduce water and soil loss, improve the regional ecological environment, and enhance the public welfare of the mining area [62-64]. Vegetation rehabilitation significantly improved the primary soil physicochemical properties in the mining area, and further developed the soil bacterial communities $[12,65,66]$. Nearly half of the coal production capacity of China is concentrated in the Loess Plateau, but the local ecosystem has become very fragile. Damage due to mining usually worsens the local ecological environment, and vegetation rehabilitation effectively increases surface coverage, reduces soil erosion, and conserves soil fertility [13,22,58-61]. In this study, the structures, compositions, and interactions of soil bacterial communities in the mining subsidence area, vegetation rehabilitation area, and their corresponding control groups in the Loess Plateau were analyzed. These results will aid in the understanding the soil bacterial adaptability to the soil environments after mining subsidence and vegetation rehabilitation in the mining areas of the Loess Plateau. This work provides information on the screening of potential strains, with high adaptability for the remediation of the local ecosystems in the Loess Plateau.

\subsection{Effects of Mining Subsidence and Vegetation Rehabilitation on the Soil Physicochemical Properties}

Mining subsidence has a significantly complex impact on soil physicochemical properties. The changes in soil physicochemical properties in the mining subsidence area of the Daliuta Coal Mine show reduced OM, seriously depleted nutrients, and much declined soil fertility, consistent with the conclusions drawn in previous studies $[22,23,26,67]$. The clarification of these changes and their causes for mine ecological restoration is of great significance. After the mining subsidence, SWC and spatial variability increased. This is usually related to surface cracks and local ponding, which block the hydrological process at a sloped surface and reduce land productivity [68,69]. Further, ST and fluctuation decreased, which might be closely related to SWC [70,71]. However, pH increased slightly, which is related to the increase in SWC. The $\mathrm{Ca}^{2+}$ and $\mathrm{Mg}^{2+}$ ions in the soil are easier to precipitate and bond with $\mathrm{OH}-$, thus increasing the alkalinity of soil [72,73].

Vegetation rehabilitation has a positive impact on soil physicochemical properties. The changes in soil physicochemical properties in the vegetation rehabilitation area of the Heidaigou Coal Mine indicate a slight increase in $\mathrm{OM}$, and an increase in the contents of soil nitrogen, phosphorus, and potassium, consistent with the observations of previous studies [65,66]. Wang et al. [74] suggested that land reclamation could effectively improve the soil quality, and gradually improve the original level with the increase in reclamation period. In this study, soil physicochemical properties were also significantly positively affected by vegetation rehabilitation. SWC in the vegetation rehabilitation area was significantly higher than that in the control group, as per the results of Cao et al. [75]. Nevertheless, the improvement of SWC was assigned to human management in previous studies $[4,9,10,22]$. The decrease of ST in the vegetation rehabilitation area was attributed to loose soil, according to other studies $[63,64,76,77]$. Considering the experimental results of the present work, we prefer to correlate the decrease in ST with the decrease in bare soil, due to the increase in plant- coverage. The increase of soil $\mathrm{pH}$ in the vegetation rehabilitation area might be related to the materials used in field leveling or due to the improvement of soil moisture content to increase the contents of $\mathrm{Ca}^{2+}$ and $\mathrm{Mg}^{2+}$ ions in the soil solutions. 


\subsection{Changes in Soil Bacterial Communities after Mining Subsidence and Vegetation Rehabilitation}

Mining subsidence was shown to exert a significant impact on soil bacterial diversity [78-80]. In the Daliuta Coal Mine, the abundance and homogeneity of soil bacterial communities decreased after mining subsidence, although there was no change in the primary bacterial phyla. Our results are consistent with those of de Quadros et al. [37] and Li et al. [81]. Mining subsidence changed the original support basement of soil environment, exhibiting a serious interference with the rhizosphere bacteria $[78,79,82]$. Soil bacteria were inevitably negatively affected [80]. However, due to technological limitations, the research on the interactions between soil bacteria subjected to mining subsidence has not been reported previously. In this study, the molecular ecological network analysis was adopted to explore the relationships between soil bacterial species. The results of this study show that the number of connecting lines, average clustering coefficient, average path distance and density of the soil bacterial molecular ecological network were higher than those of the control group, indicating enhanced complexity of the soil bacterial molecular ecological network after mining subsidence, the increased connectivity strength between nodes and the positive correlations, with closer connections between network nodes. These results indicate that soil bacteria can cooperate with each other to adapt to the nutrients loss in the unfavorable habitat caused by mining subsidence. However, the modularity index of the molecular ecological network of the mining subsidence area was smaller than that of the control group, indicating the weakened resistance of bacterial communities to external changes due to mining subsidence.

Vegetation rehabilitation can effectively improve the diversity of a soil bacterial community, as evidenced by this work and previous studies [29,39,40,42,82-85]. The number of connections between nodes after the reclamation was significantly smaller than that in the control group. Additionally, the number of network modules of the vegetation rehabilitation area was greater than that of the control group, and the relationship between modules changed from competition to cooperation. The network modularity index of the vegetation rehabilitation area was significantly higher than that of the control group, indicating significantly enhanced resistance of bacteria to external changes, and that the vegetation rehabilitation promoted the development of bacterial communities.

Furthermore, an analysis of the interactions between soil bacterial species after the mining subsidence and vegetation rehabilitation showed that after the variations or fluctuations of external environments, soil bacterial species cooperated with each other to adapt to the changing environments, although with similar ecological niches. This phenomenon plays an important role in the stable regulation and evolution of natural systems, and also reflects the sensitivity and adaptability of key species to the changes in the soil environment [86]. A similar trend was observed in the extreme environment threatened by $\mathrm{CO}_{2}$, and soil bacteria $[49,50]$.

\subsection{Interactions between Soil Bacterial Communities and Environmental Factors in both Ecological Processes}

The soil bacteria were closely correlated to the physicochemical properties in both ecological processes. At the phylum level, the results of RDA analysis showed that the sampling points of the mining subsidence area and control group in the Daliuta Coal Mine intertwined without obvious differentiation. However, the sampling points of the vegetation rehabilitation area and control group in the Heidaigou Coal Mine differed spatially to a certain extent. The sampling points of the vegetation rehabilitation area showed obvious clustering, confirming the positive role of artificial restoration [85]. On the level of OTU, the soil bacterial communities in the mining subsidence area of the Daliuta Coal Mine correlated significantly positively with NN, indicating that the loss of soil nitrate-nitrogen caused by the subsidence might be the most important driving force for the evolution of the bacterial community structure. Soil bacterial communities of the vegetation rehabilitation area of the Heidaigou Coal Mine correlated significantly with ST, AP, AK, NN, and AN. Although soil nutrients (AP and NN) were still the dominant factors for the development of bacterial communities, the increase of plants coverage after reclamation significantly changed the soil temperature and gas emissions, weakened the 
impact of environmental factors on bacteria, enhanced the cooperation between bacterial communities, and significantly enhanced the stability of the soil environment.

The network constructed using genera and environmental factors showed that Variibacter in the Daliuta Coal Mine correlated negatively with $\mathrm{pH}, \mathrm{EC}$, and NN, but positively with ST and AN. This strain, therefore, has the potential for the monitoring and abatement of soil quality in subsidence areas, wherein, soil $\mathrm{pH}$ closely positively related to the dominant genus Variibacter. $\mathrm{pH}$ is a dominant factor for the difference in the horizontal structure of bacterial communities in the subsidence area of the Daliuta Coal Mine. This result is consistent with the conclusion drawn by Shen et al. [87], that the bacterial communities in the vertical zone of the Changbai Mountain were dominated by $\mathrm{pH}$. Similar conclusions were also drawn by Dimitriu et al. [30], that after reclamation, the bacterial structures were mainly determined by $\mathrm{pH}$ and other soil abiotic characteristics. We also suggest that the difference in terrains caused by subsidence aggravated the differentiation of soil $\mathrm{pH}$, water, and nutrients. This might further affect the development of soil bacterial communities. The molecular ecological network of the vegetation rehabilitation area in the Heidaigou Mine formed a radial distribution with a center of Solirubrobacter. OM and AK closely and negatively correlated with Solirubrobacter, showing that the nutrients, particularly OM and AK, were the dominant factors for the development of soil bacterial communities. Therefore, Solirubrobacte could serve as the dominant and crucial strain, indicating the improvement of the quality of sandy soil in the Loess Plateau.

\subsection{Uncertainties of Soil Bacterial Development in Ecological Processes caused by Mining Activities}

The effects of ecological processes due to mining activities on the development of soil bacterial communities still had several uncertainties. Geographical locations, meteorological conditions, seasons, mining intensity and other factors may cause the spatial heterogeneity in soil bacterial communities and physicochemical properties.

The geographic locations, or biogeography, can affect the development of soil bacterial communities [88-94]. Although both the Daliuta and Heidaigou Coal Mines are located at the northern edge of the Loess Plateau, they differed in soil bacterial diversity, community structure, and composition. In 1934, Bass-Becking reported that "Everything is everywhere, but the environment selects", suggesting that bacteria have the characteristics of small size, large quantity, short generation cycle, high diffusion rate, and no restriction on diffusion [88,95]. Later, the distributions of soil bacteria were shown to be similar to those of large-size animals and plants [89,90], and these distributions were affected by regional environmental screening, interactions between species, and random diffusion screening [91-94]. These laws can also be applied to different areas disturbed by coal mining.

Meteorological conditions, especially temperature and precipitation, are important factors affecting bacterial diversity and community composition [96]. Temperature led to the differentiation of ammonia-oxidizing bacterial communities [97]. Low temperature also reduced the promotion effect of AM fungi on the nutrient uptake by plants [98]. The grasslands in North China are dry (AI < 0.32). With the increase of dryness index, the total number of nitrifying and denitrifying bacteria in soil increased, and the number of soil bacteria declined dramatically, due to seasonal drought [99]. Altitude also affects the composition of the bacterial community [100]. The meteorological conditions of the Daliuta and Heidaigou Coal Mines are different to a certain extent. Thus, the long-term meteorological conditions modified the soil bacteria, forming the stable states of soil bacterial communities.

Seasonal differences, i.e., the differences in the sampling times of soil bacteria, also interfered with the changes in soil bacterial community structures evaluated by sequencing. Previous studies have confirmed the effects of seasons on the diversity of soil bacterial communities [101-103]. Considering the interference of seasonal differences, the sampling in this study was performed from August 15-23, 2018, during which the soil bacteria were stably active.

Next, the mining intensity has a direct relationship with the mining subsidence, thus changing the physical and chemical properties of soil and further interfering with the soil bacterial communities [7,10,38,96,104]. 
The effects of several other possible factors on the soil bacterial communities were not negligible, and these effects are still under investigation. A quantitative study on the significance of these effects on soil bacterial species and their corresponding interactions is still required. Finally, the impact of some other possible factors affecting soil bacterial communities needs to be further recognized.

\section{Conclusions}

A comprehensive and systematic understanding of the evolution of soil bacterial communities in damaged mines is not only essential to the ecological restoration and abatement of the mining areas, but also crucial to improving the livelihood of the local residents and ecosystem services. In this study, field investigations, high-throughput sequencing, and molecular ecological network analyses were carried out to explore the changes in soil environment and differences in bacterial communities after the mining subsidence and reclamation in the Loess Plateau.

(1) Mining subsidence and vegetation rehabilitation exerted significant effects on soil physicochemical properties. Mining subsidence exhibited negative effects by decreasing the soil temperature and organic matter, available phosphorus, available potassium, and nitrate nitrogen. Vegetation rehabilitation exhibited positive effects by increasing the content of soil water, $\mathrm{pH}, \mathrm{EC}$, and contents of organic matter, available phosphorus, available potassium, nitrate-nitrogen, and ammonium nitrogen, but exerted a negative impact on soil temperature.

(2) The effects of mining subsidence and vegetation rehabilitation on the diversity of soil bacterial communities were rather varied. Mining subsidence led to a decrease of $20 \%$ in the Chao1 and ACE indexes of bacterial communities, while the vegetation rehabilitation led to a corresponding increase of $63 \%$ in these indexes. However, mining subsidence and vegetation rehabilitation did not change the dominant phyla in the soil, and the relative abundance of dominant phyla varied slightly.

(3) Mining subsidence and vegetation rehabilitation had a significant impact on the soil bacterial molecular ecological network. Mining subsidence increased the complexity of the connections within the network. The degree of concentration and number of connections of the network increased, with a concomitant increase in the positive correlations. While vegetation rehabilitation increased the diversification of the network, the connections were weakened.

(4) The interactions between soil bacteria changed to adapt to the interference due to mining. Mining subsidence promoted the cooperation between bacterial genera for the adaption to survival. Vegetation rehabilitation promoted the complexity of modules and the cooperation between bacteria to acquire more external resources. Variibacter could serve as the indicator strain for soil quality improvement after the subsidence, and Solirubrobacte could be adopted as an indicator to assess the improvement of the quality of sandy soil, but this hypothesis needs further study.

Author Contributions: Conceptualization, Z.L., J.M. and F.C.; methodology, Z.L., J.M. and F.C.; software, Z.L. and J.M.; validation, Z.L., J.M., F.C., X.L., Q.Z. and Y.Y.; formal analysis, Z.L. and J.M.; investigation, Z.L., J.M., F.C., X.L., Q.Z. and Y.Y.; resources, F.C.; data curation, Z.L., J.M., F.C., X.L., Q.Z. and Y.Y.; writing-original draft preparation, Z.L., J.M. F.C., and X.L.; writing-review and editing, Z.L., J.M. F.C., and X.L.; visualization, Z.L., J.M. and F.C.; supervision, F.C.; project administration, F.C.; funding acquisition, F.C. All authors have read and agreed to the published version of the manuscript.

Funding: This research was funded by the National Natural Science Foundation of China $(51974313,41907405)$ and the Natural Science Foundation of Jiangsu Province (BK20180641).

Acknowledgments: The authors would like to thank Mapletrans English Service for providing English language, grammar, punctuation, and spelling help during the preparation of this manuscript.

Conflicts of Interest: The authors declare no conflict of interest. The funders had no role in the design of the study; the collection, analyses, or interpretation of data; the writing of the manuscript, or in the decision to publish the results. 


\section{References}

1. Hartley, H. Coal Mining in Great Britain. Nature 1945, 155, 685-687. [CrossRef]

2. Dodson, J.; Li, X.Q.; Sun, N.; Atahan, P.; Zhou, X.Y.; Liu, H.B.; Zhao, K.L.; Hu, S.M.; Yang, Z.M. Use of coal in the Bronze Age in China. Holocene 2014, 24, 525-530. [CrossRef]

3. Yuan, J. The future of coal in China. Resour. Conserv. Recy. 2018, 129, 290-292. [CrossRef]

4. Zhao, Z.; Shahrour, I.; Bai, Z.; Fan, W.; Feng, L.; Li, H. Soils development in opencast coal mine spoils reclaimed for 1-13 years in the West-Northern Loess Plateau of China. Eur. J. Soil Biol. 2013, 55, 40-46. [CrossRef]

5. Bian, Z.F.; Dong, J.H.; Lei, S.G.; Leng, H.L.; Mu, S.G.; Wang, H. The impact of disposal and treatment of coal mining wastes on environment and farmland. Environ. Geol. 2009, 58, 625-634. [CrossRef]

6. Qi, Y.; Stern, N.; Wu, T.; Lu, J.Q.; Green, F. China's post-coal growth. Nat. Geosci. 2016, 9, 564-566. [CrossRef]

7. Bian, Z.; Miao, X.; Lei, S.; Chen, S.-e.; Wang, W.; Struthers, S. The Challenges of Reusing Mining and Mineral-Processing Wastes. Science 2012, 337, 702-703. [CrossRef]

8. Bian, Z.; Inyang, H.I.; Daniels, J.L.; Otto, F.; Struthers, S. Environmental issues from coal mining and their solutions. Min. Sci. Technol. 2010, 20, 215-223. [CrossRef]

9. Hu, Z.; Wang, P.; Li, J. Ecological restoration of abandoned mine land in China. J. Resour. Ecol. 2012, 3, 289-297. [CrossRef]

10. Bai, Z.; Zhou, W.; Wang, J.; Zhao, Z.; Cao, Y.; Zhou, Y. Rethink on Ecosystem Restoration and Rehabilitation of Mining Areas. China Land Sci. 2018, 32, 1-9. (In Chinese)

11. Zhang, X.; Ren, Y. Study on land damage prediction and reclamation planning in coal mining areas. China Coal 2018, 44, 138-144. (In Chinese)

12. Bi, Y.; Wang, K.; Wang, J. Effect of different inoculation treatments on AM fungal communities and the sustainability of soil remediation in Daliuta coal mining subsidence area in northwest China. Appl. Soil Ecol. 2018, 132, 107-113. [CrossRef]

13. Bi, Y.; Xie, L.; Wang, J.; Zhang, Y.; Wang, K. Impact of host plants, slope position and subsidence on arbuscular mycorrhizal fungal communities in the coal mining area of north-central China. J. Arid. Environ. 2019, 163, 68-76. [CrossRef]

14. Luo, Z.; Ma, J.; Chen, F.; Li, X.; Hou, H.; Zhang, S. Cracks Reinforce the Interactions among Soil Bacterial Communities in the Coal Mining Area of Loess Plateau, China. Int. J. Environ. Res. Public Health 2019, 16, 4892. [CrossRef] [PubMed]

15. Bi, Y.; Zou, H.; Peng, C.; Shi, L. Effects of mining subsidence on soil water movement in sandy area. J. China Coal Soc. 2014, 39, 490-496. (In Chinese)

16. Lei, S.G.; Xiao, H.Y.; Qie, C.L.; Bian, Z.F.; Yang, D.J.; Piao, C.D. Similar simulation experiment on the influence of mining subsidence on the key physical properties of soil. J. China Coal Soc. 2017, 42, 300-307. (In Chinese)

17. Qie, C.L.; Bian, Z.F.; Yang, D.J.; Lei, S.G.; Mu, S.G. Effect of high-intensity underground coal mining disturbance on soil physical properties. J. China Coal Soc. 2015, 40, 1448-1456.

18. Bi, Y.; Zou, H.; Zhu, C. Dynamic monitoring of soil bulk density and infiltration rate during coal mining in sandy land with different vegetation. Int. J. Coal Sci. Technol. 2014, 1, 198-206. [CrossRef]

19. Yao, G.; Ding, G.; Zang, Y.; Ji, W.; Yong, G.; Zhou, R.; Jian, W.; Zhi, H.; Bo, X.; Gao, J. Soil quality evaluation of windy desert region after coal mining subsidence based on discriminant and factor analysis. Trans. Chin. Soc. Agric. Eng. 2012, 28, 200-207. (In Chinese)

20. Zhao, G.; Bi, Y.; Wei, Y.; Shi, Z.; Xu, L. The Impact of Coal Mining Subsiding on Particle Size Composition in Shenfu Coalfield. J. Desert Res. 2015. (In Chinese)

21. Rai, A.K.; Paul, B.; Singh, G. Assessment of top soil quality in the vicinity of subsided area in the south eastern part of Jharia Coalfield, Jharkhand, India. Rep. Opin. 2009, 12, 137-146.

22. Jing, Z.; Wang, J.; Zhu, Y.; Feng, Y. Effects of land subsidence resulted from coal mining on soil nutrient distributions in a loess area of China. J. Cleaner Product. 2018, 177, 350-361. [CrossRef]

23. Tripathi, N.; Singh, R.S.; Singh, J.S. Impact of post-mining subsidence on nitrogen transformation in southern tropical dry deciduous forest, India. Environ. Res. 2009, 109, 258-266. [CrossRef] [PubMed]

24. Srivastava, N.K.; Ram, L.C.; Masto, R.E. Reclamation of overburden and lowland in coal mining area with fly ash and selective plantation: A sustainable ecological approach. Ecol. Eng. 2014, 71, 479-489. [CrossRef] 
25. Miao, Z.; Marrs, R. Ecological restoration and land reclamation in open-cast mines in Shanxi Province, China. J. Environ. Manag. 2000, 59, 205-215. [CrossRef]

26. Wang, J.; Wang, P.; Qin, Q.; Wang, H. The effects of land subsidence and rehabilitation on soil hydraulic properties in a mining area in the Loess Plateau of China. Catena 2017, 159, 51-59. [CrossRef]

27. Akala, V.A.; Lal, R. Potential of mine land reclamation for soil organic carbon sequestration in ohio. Land Degrad. Dev. 2000, 11, 289-297. [CrossRef]

28. Wang, J.M.; Ma, J.J.; Yao, H.; Lv, S.H. Biodiversity of grassland communities and spatial variability of functional groups in the mongolica forest-steppe ecotone. Fresenius Environ. Bull. 2015, 24, 2707-2714.

29. Chodak, M.; Pietrzykowski, M.; Niklinska, M. Development of microbial properties in a chronosequence of sandy mine soils. Appl. Soil Ecol. 2009, 41, 259-268. [CrossRef]

30. Dimitriu, P.A.; Prescott, C.E.; Quideau, S.A.; Grayston, S.J. Impact of reclamation of surface-mined boreal forest soils on microbial community composition and function. Soil Biol. Biochem. 2010, 42, 2289-2297. [CrossRef]

31. Pace, N.R. A molecular view of microbial diversity and the biosphere. Science 1997, 276, 734-740. [CrossRef]

32. Delgado-Baquerizo, M.; Oliverio, A.M.; Brewer, T.E.; Benavent-González, A.; Eldridge, D.J.; Bardgett, R.D.; Maestre, F.T.; Singh, B.K.; Fierer, N. A global atlas of the dominant bacteria found in soil. Science 2018, 359, 320-325. [CrossRef] [PubMed]

33. Harris, J. Soil Microbial Communities and Restoration Ecology: Facilitators or Followers? Science 2009, 325, 573-574. [CrossRef] [PubMed]

34. Cong, J.; Yang, Y.F.; Liu, X.D.; Lu, H.; Liu, X.; Zhou, J.Z.; Li, D.Q.; Yin, H.Q.; Ding, J.J.; Zhang, Y.G. Analyses of soil microbial community compositions and functional genes reveal potential consequences of natural forest succession. Sci Rep. 2015, 5. [CrossRef] [PubMed]

35. Zhu, Y.; Shen, R.; He, J.; Wang, Y.; Han, X.; Jia, Z. China Soil Microbiome Initiative: Progress and Perspective. Bull. Chin. Acad. Sci. 2017, 32, 554-565. (In Chinese)

36. Yang, T.; Adams, J.M.; Shi, Y.; He, J.S.; Jing, X.; Chen, L.T.; Tedersoo, L.; Chu, H.Y. Soil fungal diversity in natural grasslands of the Tibetan Plateau: Associations with plant diversity and productivity. New Phytol. 2017, 215, 756-765. [CrossRef]

37. de Quadros, P.D.; Zhalnina, K.; Davis-Richardson, A.G.; Drew, J.C.; Menezes, F.B.; Camargo, F.A.D.; Triplett, E.W. Coal mining practices reduce the microbial biomass, richness and diversity of soil. Appl. Soil Ecol. 2016, 98, 195-203. [CrossRef]

38. Li, Y.; Chen, L.; Wen, H.; Zhou, T.; Zhang, T.; Gao, X. 454 Pyrosequencing Analysis of Bacterial Diversity Revealed by a Comparative Study of Soils from Mining Subsidence and Reclamation Areas. J. Microbiol. Biotechnol. 2014, 24, 313-323. [CrossRef]

39. Mummey, D.L.; Stahl, P.D.; Buyer, J.S. Soil microbiological properties 20 years after surface mine reclamation: Spatial analysis of reclaimed and undisturbed sites. Soil. Biol. Biochem. 2002, 34, 1717-1725. [CrossRef]

40. Helingerova, M.; Frouz, J.; Santruckova, H. Microbial activity in reclaimed and unreclaimed post-mining sites near Sokolov (Czech Republic). Ecol. Eng. 2010, 36, 768-776. [CrossRef]

41. Brooks, J.P.; Adeli, A.; Smith, R.K.; McGrew, R.; Lang, D.J.; Read, J.J. Bacterial Community Structure Recovery in Reclaimed Coal Mined Soil under Two Vegetative Regimes. J. Environ. Qual. 2019, 48, 1029-1037. [CrossRef] [PubMed]

42. Dangi, S.R.; Stahl, P.D.; Wick, A.F.; Ingram, L.J.; Buyer, J.S. Soil Microbial Community Recovery in Reclaimed Soils on a Surface Coal Mine Site. Soil Sci. Soc. Am. J. 2012, 76, 915-924. [CrossRef]

43. Pascual, J.; Garcia, C.; Hernandez, T.; Moreno, J.; Ros, M. Soil microbial activity as a biomarker of degradation and remediation processes. Soil Biol. Biochem. 2000, 32, 1877-1883. [CrossRef]

44. Harris, J.A. Measurements of the soil microbial community for estimating the success of restoration. Eur. J. Soil Sci. 2003, 54, 801-808. [CrossRef]

45. Tian, J.; He, N.; Kong, W.; Deng, Y.; Feng, K.; Green, S.M.; Wang, X.; Zhou, J.; Kuzyakov, Y.; Yu, G. Deforestation decreases spatial turnover and alters the network interactions in soil bacterial communities. Soil Biol. Biochem. 2018, 123, 80-86. [CrossRef]

46. Deng, Y.; Jiang, Y.H.; Yang, Y.F.; He, Z.L.; Luo, F.; Zhou, J.Z. Molecular ecological network analyses. BMC Bioinform. 2012, 13, 113. [CrossRef] [PubMed]

47. Barberán, A.; Bates, S.T.; Casamayor, E.O.; Fierer, N. Using network analysis to explore co-occurrence patterns in soil microbial communities. ISME J. 2012, 6, 343-351. [CrossRef] [PubMed] 
48. Banerjee, S.; Kirkby, C.A.; Schmutter, D.; Bissett, A.; Kirkegaard, J.A.; Richardson, A.E. Network analysis reveals functional redundancy and keystone taxa amongst bacterial and fungal communities during organic matter decomposition in an arable soil. Soil Biol. Biochem. 2016, 97, 188-198. [CrossRef]

49. Ma, J.; Luo, Z.; Chen, F.; Chen, R.; Zhu, Q.; Zhang, S. Impacts of Elevated CO2 Levels on the Soil Bacterial Community in a Natural CO2-Enhanced Oil Recovery Area. Diversity 2019, 11, 19. [CrossRef]

50. Zhou, J.Z.; Deng, Y.; Luo, F.; He, Z.L.; Yang, Y.F. Phylogenetic Molecular Ecological Network of Soil Microbial Communities in Response to Elevated $\mathrm{CO}_{2}$. MBio 2011, 2, e00122-00111. [CrossRef]

51. Lu, L.; Yin, S.; Liu, X.; Zhang, W.; Gu, T.; Shen, Q.; Qiu, H. Fungal networks in yield-invigorating and -debilitating soils induced by prolonged potato monoculture. Soil Biol. Biochem. 2013, 65, 186-194. [CrossRef]

52. Wang, S.; Wang, X.; Han, X.; Deng, Y. Higher precipitation strengthens the microbial interactions in semi-arid grassland soils. Glob. Ecol. Biogeogr. 2018, 27, 570-580. [CrossRef]

53. Ma, J.; Lu, Y.; Chen, F.; Li, X.; Xiao, D.; Wang, H. Molecular Ecological Network Complexity Drives Stand Resilience of Soil Bacteria to Mining Disturbances among Typical Damaged Ecosystems in China. Microorganisms 2020, 8, 433. [CrossRef] [PubMed]

54. Bao, S. Soil and Agricultural Chemistry Analysis; China Agricultural Science and Technology Press: Beijing, China, 2000.

55. Otasek, D.; Morris, J.H.; Boucas, J.; Pico, A.R.; Demchak, B. Cytoscape Automation: Empowering workflow-based network analysis. Genome Biol. 2019, 20. [CrossRef] [PubMed]

56. Jung, H.C.; Kim, S.W.; Jung, H.S.; Min, K.D.; Won, J.S. Satellite observation of coal mining subsidence by persistent scatterer analysis. Eng. Geol. 2007, 92, 1-13. [CrossRef]

57. Duzgun, S.; Kunzer, C.; Karacan, C.O. Applications of remote sensing and GIS for monitoring of coal fires, mine subsidence, environmental impacts of coal-mine closure and reclamation Preface. Int. J. Coal Geol. 2011, 86, 1-2. [CrossRef]

58. Wu, Q.Y.; Pang, J.W.; Qi, S.Z.; Li, Y.P.; Han, C.C.; Liu, T.X.; Huang, L.M. Impacts of coal mining subsidence on the surface landscape in Longkou city, Shandong Province of China. Environ. Earth Sci. 2009, 59, 783-791. [CrossRef]

59. Shepley, M.G.; Pearson, A.D.; Smith, G.D.; Banton, C.J. The impacts of coal mining subsidence on groundwater resources management of the East Midlands Permo-Triassic Sandstone aquifer, England. Q J. Eng. Geol. Hydroge 2008, 41, 425-438. [CrossRef]

60. Singh, G.; Paul, B.C. Assessment of groundwater quality impacts due to use of coal combustion byproducts to control subsidence from underground mines. Environ. Int. 2001, 26, 567-571. [CrossRef]

61. Yang, D.; Bian, Z.; Lei, S. Impact on soil physical qualities by the subsidence of coal mining: A case study in Western China. Environ. Earth Sci. 2016, 75. [CrossRef]

62. Gilbert, C.; Ayanda, O.S.; Fatoba, O.O.; Madzivire, G.; Petrik, L.F. A Novel Method of Using Iron Nanoparticles from Coal Fly Ash or Ferric Chloride for Acid Mine Drainage Remediation. Mine Water Environ. 2019, 38, 617-631. [CrossRef]

63. Tong, L.; Leo, L.; Amatya, B.; Liu, S. Risk assessment and remediation strategies for highway construction in abandoned coal mine region: Lessons learned from Xuzhou, China. B Eng. Geol. Environ. 2016, 75, 1045-1066. [CrossRef]

64. Bulusu, S.; Aydilek, A.H.; Petzrick, P.; Guynn, R. Remediation of abandoned mines using coal combustion by-products. J. Geotech. Geoenviron. 2005, 131, 958-969. [CrossRef]

65. Lefticariu, L.; Walters, E.R.; Pugh, C.W.; Bender, K.S. Sulfate reducing bioreactor dependence on organic substrates for remediation of coal-generated acid mine drainage: Field experiments. Appl. Geochem. 2015, 63, 70-82. [CrossRef]

66. Bott, T.L.; Jackson, J.K.; McTammany, M.E.; Newbold, J.D.; Rier, S.T.; Sweeney, B.W.; Battle, J.M. Abandoned coal mine drainage and its remediation: Impacts on stream ecosystem structure and function. Ecol. Appl. 2012, 22, 2144-2163. [CrossRef] [PubMed]

67. Qu, J.; Tan, M.; Hou, Y.; Ge, M.; Wang, A.; Wang, K.; Shan, J.; Chen, F. Effects of the Stability of Reclaimed Soil Aggregates on Organic Carbon in Coal Mining Subsidence Areas. Appl. Eng. Agric. 2018, 34, 843-854. [CrossRef]

68. Sanmiquel, L.; Bascompta, M.; Vintro, C.; Yubero, T. Subsidence Management System for Underground Mining. Minerals 2018, 8, 243. [CrossRef] 
69. Su, H.C.; Lin, H.I. A novel flood management strategy to plan eco-industry development in areas of coastal land-subsidence in Taiwan. Can. J. Civil. Eng 2010, 37, 553-561. [CrossRef]

70. Yang, K.; Wang, C. Water storage effect of soil freeze-thaw process and its impacts on soil hydro-thermal regime variations. Agric. Forest Meteorol. 2019, 265, 280-294. [CrossRef]

71. Vidana Gamage, D.N.; Biswas, A.; Strachan, I.B. Spatial variability of soil thermal properties and their relationships with physical properties at field scale. Soil Tillage Res. 2019, 193, 50-58. [CrossRef]

72. Colombani, N.; Mastrocicco, M.; Giambastiani, B.M.S. Predicting Salinization Trends in a Lowland Coastal Aquifer: Comacchio (Italy). Water Resour. Manag. 2015, 29, 603-618. [CrossRef]

73. Shrestha, R.K.; Lal, R. Changes in physical and chemical properties of soil after surface mining and reclamation. Geoderma 2011, 161, 168-176. [CrossRef]

74. Wang, J.; Guo, L.; Bai, Z.; Yang, R.; Zhang, M. Succession law of reclaimed soil and vegetation on opencast coal mine dump of loess area. Trans. Chin. Soc. Agric. Eng. 2013, 29, $223-232$.

75. Cao, Y.; Wang, J.; Bai, Z.; Zhou, W.; Zhao, Z.; Ding, X.; Li, Y. Differentiation and mechanisms on physical properties of reconstructed soils on open-cast mine dump of loess area. Environ. Earth Sci. 2015, 74, 6367-6380. [CrossRef]

76. Geremias, R.; Pedrosa, R.C.; Benassi, J.C.; Favere, V.T.; Stolberg, J.; Menezes, C.T.B.; Laranjeira, M.C.M. Remediation of coal mining wastewaters using chitosan microspheres. Environ. Technol. 2003, 24, 1509-1515. [CrossRef]

77. Hinkle, M.; Ling, F.; Heaney, P.; Post, J. Structural variability in manganese oxides produced at a coal mine drainage remediation site. Abstr. Pap. Am. Chem. S 2018, 255.

78. Li, S.; Bi, Y.; Kong, W.; Yu, H.; Lang, Q.; Miao, Y. Effects of arbuscular mycorrhizal fungi on ecological restoration in coal mining areas. Russ. J. Ecol. 2015, 46, 431-437. [CrossRef]

79. Wang, J. Impacts of Coal Mining Disturbance on Rhizosphere Micro-ecological and Microbial Reclamation Effect in Western Area of China. PhD Thesis, China University of Mining and Technology (Beijing), Beijing, China, 2015.

80. Shi, P.; Zhang, Y.; Hu, Z.; Ma, K.; Yu, B. Influence mechanism of coal mining subsidence on soil quality and restoration measures in west China aeolian sand area. J. Uni. Chin. Acad. Sci. 2017, 34, 318-328.

81. Li, Y.; Chen, L.; Wen, H.; Zhou, T.; Zhang, T. Pyrosequencing-based assessment of bacterial community structure in mine soils affected by mining subsidence. Int. J. Min. Sci. Technol. 2014, 24, 701-706. [CrossRef]

82. Bi, Y.; Zhang, Y. Role of the different planting age of seabuckthorn forests to soil amelioration in coal mining subsidence land. Int. J. Coal Sci. Technol. 2014, 1, 192-197. [CrossRef]

83. Mastrogianni, A.; Papatheodorou, E.M.; Monokrousos, N.; Menkissoglu-Spiroudi, U.; Stamou, G.P. Reclamation of lignite mine areas with Triticum aestivum: The dynamics of soil functions and microbial communities. Appl. Soil Ecol. 2014, 80, 51-59. [CrossRef]

84. Bi, Y.; Shen, H. Effect of micro-reclamation on different planted forest on the vegetation self-succession in the western mining subsidence area. J. China Coal Soc. 2019, 44, 307-315. (In Chinese)

85. Li, Y.Y.; Wen, H.Y.; Chen, L.Q.; Yin, T.T. Succession of Bacterial Community Structure and Diversity in Soil along a Chronosequence of Reclamation and Re-Vegetation on Coal Mine Spoils in China. PLoS ONE 2014, 9 , e115024. [CrossRef] [PubMed]

86. Jiang, Y.; Li, S.; Li, R.; Zhang, J.; Liu, Y.; Lv, L.; Zhu, H.; Wu, W.; Li, W. Plant cultivars imprint the rhizosphere bacterial community composition and association networks. Soil Biol. Biochem. 2017, 109, 145-155. [CrossRef]

87. Shen, C.C.; Xiong, J.B.; Zhang, H.Y.; Feng, Y.Z.; Lin, X.G.; Li, X.Y.; Liang, W.J.; Chu, H.Y. Soil pH drives the spatial distribution of bacterial communities along elevation on Changbai Mountain. Soil Biol. Biochem. 2013, 57, 204-211. [CrossRef]

88. Lepere, C.; Domaizon, I.; Taib, N.; Mangot, J.F.; Bronner, G.; Boucher, D.; Debroas, D. Geographic distance and ecosystem size determine the distribution of smallest protists in lacustrine ecosystems. FEMS Microbiol. Ecol. 2013, 85, 85-94. [CrossRef]

89. Green, J.; Bohannan, B.J.M. Spatial scaling of microbial biodiversity. Trends Ecol. Evol. 2006, 21, 501-507. [CrossRef]

90. Martiny, J.B.H.; Eisen, J.A.; Penn, K.; Allison, S.D.; Horner-Devine, M.C. Drivers of bacterial $\beta$-diversity depend on spatial scale. Proc. Natl. Acad. Sci. USA 2011, 108, 7850-7854. [CrossRef]

91. Fierer, N.; Jackson, R.B. The diversity and biogeography of soil bacterial communities. Proc. Natl. Acad. Sci. USA 2006, 103, 626-631. [CrossRef] 
92. Horner-Devine, M.C.; Lage, M.; Hughes, J.B.; Bohannan, B.J.M. A taxa-area relationship for bacteria. Nature 2004, 432, 750-753. [CrossRef]

93. Whitaker, R.J.; Grogan, D.W.; Taylor, J.W. Geographic barriers isolate endemic populations of hyperthermophilic archaea. Science 2003, 301, 976-978. [CrossRef]

94. Zhou, J.Z.; Kang, S.; Schadt, C.W.; Garten, C.T. Spatial scaling of functional gene diversity across various microbial taxa. Proc. Natl. Acad. Sci. USA 2008, 105, 7768-7773. [CrossRef] [PubMed]

95. Baas-Becking, L.G.M. Geobiologie of Inleiding tot de Milieukunde; WP Van Stockum \& Zoon NV: The Hague, The Netherlands, 1934.

96. Hu, Z.; Chen, C.; Xiao, W.; Wang, X.; Gao, M. Surface movement and deformation characteristics due to high-intensive coal mining in the windy and sandy region. Int. J. Coal Sci. Technol. 2016, 3, 339-348. [CrossRef]

97. Fierer, N.; Carney, K.M.; Horner-Devine, M.C.; Megonigal, J.P. The Biogeography of Ammonia-Oxidizing Bacterial Communities in Soil. Microb. Ecol. 2009, 58, 435-445. [CrossRef] [PubMed]

98. Kytoviita, M.M.; Ruotsalainen, A.D. Mycorrhizal benefit in two low arctic herbs increases with increasing temperature. Am. J. Bot. 2007, 94, 1309-1315. [CrossRef]

99. Wang, C.; Wang, X.B.; Liu, D.W.; Wu, H.H.; Lu, X.T.; Fang, Y.T.; Cheng, W.X.; Luo, W.T.; Jiang, P.; Shi, J.S.; et al. Aridity threshold in controlling ecosystem nitrogen cycling in arid and semi-arid grasslands. Nat. Commun. 2014, 5. [CrossRef]

100. Bryant, J.A.; Lamanna, C.; Morlon, H.; Kerkhoff, A.J.; Enquist, B.J.; Green, J.L. Microbes on mountainsides: Contrasting elevational patterns of bacterial and plant diversity. Proc. Natl. Acad. Sci. USA 2008, 105, 11505. [CrossRef]

101. Bossio, D.A.; Scow, K.M.; Gunapala, N.; Graham, K.J. Determinants of soil microbial communities: Effects of agricultural management, season, and soil type on phospholipid fatty acid profiles. Microb. Ecol. 1998, 36, 1-12. [CrossRef]

102. Lipson, D.A.; Schmidt, S.K. Seasonal changes in an alpine soil bacterial community in the Colorado Rocky Mountains. Appl. Environ. Microb. 2004, 70, 2867-2879. [CrossRef]

103. Habekost, M.; Eisenhauer, N.; Scheu, S.; Steinbeiss, S.; Weigelt, A.; Gleixner, G. Seasonal changes in the soil microbial community in a grassland plant diversity gradient four years after establishment. Soil Biol. Biochem. 2008, 40, 2588-2595. [CrossRef]

104. Wang, R.; Ma, S.; Zhang, H.; Xu, C.; Guo, Z. Effects of surface cracks caused by high intensity coal mining on soil microbial characteristics and plant communities in arid regions. Res. Environ. Sci. 2016, 29, 1249-1255. 